\title{
Chemogenetic Manipulations of Ventral Tegmental Area Dopamine Neurons Reveal Multifaceted Roles in Cocaine Abuse
}

\author{
(D) Stephen V. Mahler, ${ }^{1,2}$-Zachary D. Brodnik, ${ }^{3}$-Brittney M. Cox, ${ }^{1,2}$ William C. Buchta, ${ }^{2}$ Brandon S. Bentzley, ${ }^{2}$ \\ Julian Quintanilla, ${ }^{1}$ Zackary A. Cope ${ }^{2}$ Edwin C. Lin, ${ }^{2}$ Matthew D. Riedy, ${ }^{2}$ Michael D. Scofield, ${ }^{2}$ Justin Messinger, ${ }^{2}$ \\ Christina M. Ruiz, ${ }^{1}$ (D) Arthur C. Riegel, ${ }^{2}$ Rodrigo A. España, ${ }^{3}$ and $\mathbb{Q}^{-}$Gary Aston-Jones ${ }^{4}$ \\ ${ }^{1}$ Department of Neurobiology and Behavior, University of California, Irvine, Irvine, California 92697, ${ }^{2}$ Department of Neuroscience, Medical University of \\ South Carolina, Charleston, South Carolina 29425-8610, 32Department of Neurobiology and Anatomy, Drexel University, Philadelphia, Pennsylvania 19129, \\ and ${ }^{4}$ Brain Health Institute, Rutgers University, Piscataway, New Jersey 08854
}

Ventral tegmental area (VTA) dopamine (DA) neurons perform diverse functions in motivation and cognition, but their precise roles in addiction-related behaviors are still debated. Here, we targeted VTA DA neurons for bidirectional chemogenetic modulation during specific tests of cocaine reinforcement, demand, and relapse-related behaviors in male rats, querying the roles of DA neuron inhibitory and excitatory $\mathrm{G}$-protein signaling in these processes. Designer receptor stimulation of $\mathrm{G}_{\mathrm{q}}$ signaling, but not $\mathrm{G}_{\mathrm{s}}$ signaling, in $\mathrm{DA}$ neurons enhanced cocaine seeking via functionally distinct projections to forebrain limbic regions. In contrast, engaging inhibitory $\mathrm{G}_{\mathrm{i} / \mathrm{o}}$ signaling in DA neurons blunted the reinforcing and priming effects of cocaine, reduced stress-potentiated reinstatement, and altered behavioral strategies for cocaine seeking and taking. Results demonstrate that DA neurons play several distinct roles in cocaine seeking, depending on behavioral context, G-protein-signaling cascades, and DA neuron efferent targets, highlighting their multifaceted roles in addiction.

Key words: addiction; conditioned cues; DREADDs; motivation; neural circuits; reinstatement

Significance Statement

G-protein-coupled receptors are crucial modulators of ventral tegmental area (VTA) dopamine neuron activity, but how this metabotropic signaling impacts the complex roles of dopamine in reward and addiction is poorly understood. Here, we bidirectionally modulate dopamine neuron G-protein signaling with DREADDs (designer receptors exclusively activated by designer drugs) during a variety of cocaine-seeking behaviors, revealing nuanced, pathway-specific roles in cocaine reward, effortful seeking, and relapse-like behaviors. $\mathrm{G}_{\mathrm{q}}$ and $\mathrm{G}_{\mathrm{s}}$ stimulation activated dopamine neurons, but only $\mathrm{G}_{\mathrm{q}}$ stimulation robustly enhanced cocaine seeking. $G_{i / o}$ inhibitory signaling reduced some, but not all, types of cocaine seeking. Results show that VTA dopamine neurons modulate numerous distinct aspects of cocaine addiction- and relapse-related behaviors, and point to potential new approaches for intervening in these processes to treat addiction.

\section{Introduction}

Ventral tegmental area (VTA) is a crucial node in mesolimbic circuits of reward, and the $50-70 \%$ of neurons there that express

Received Feb. 4, 2018; revised 0ct. 4, 2018; accepted 0ct. 19, 2018.

Author contributions:S.V.M., Z.D.B., A.C.R., R.A.E., and G.A.-J. designed research; S.V.M., Z.D.B., B.M.C., W.C.B., J.Q., Z.A.C., E.C.L., M.D.S., J.M., C.M.R., and A.C.R. performed research; B.S.B. contributed unpublished reagents/ analytic tools; S.V.M., Z.D.B., B.M.C., W.C.B., M.D.R., M.D.S., C.M.R., A.C.R., and R.A.E. analyzed data; S.V.M. and G.A.-J. wrote the paper.

Research was funded by Public Health Service Grants K99/R00-DA-035251, R01-DA-006214, P50-DA-015369, P50-DA-044118, F31-DA-036989, T32-DA-007288, R01-DA-033342A, F31-DA-042505, R01-DA-031900, and R01DA-046476; a MUSC Department of Laboratory Animals Research Facilities Grant; and the Irvine Center for Addiction Neuroscience (University of California, Irvine). We thank Mitchell Farrell, Matthew Harberg, Hannah Schoch, and Phong Do for assistance with behavioral testing and Fos analysis; David Moorman, Elena Vazey, Morgan James, and dopamine (DA; Dobi et al., 2010) play diverse and long-debated roles in natural and drug reward-related behaviors. The activity of these neurons is extensively regulated by G-protein-coupled receptors (GPCRs), and several GPCRs are currently under investigation as therapeutic targets for the treatment (Tx) of cocaine use disorders. Nevertheless, the specific roles for DA

Peter Kalivas for helpful comments; and the NIDA Drug Distribution Program and NIMH Drug Supply Program for providing CNO.

The authors declare no competing financial interests.

Correspondence should be addressed to Stephen V. Mahler, University of California, Irvine, Department of Neurobiology and Behavior, 1203 McGaugh Hall, Irvine, CA 92697. E-mail: mahlers@uci.edu.

https://doi.org/10.1523/JNEUROSCI.0537-18.2018

Copyright $\odot 2019$ the authors $\quad 0270-6474 / 19 / 390503-16 \$ 15.00 / 0$ 
neurons in cocaine reinforcement, effortful seeking, or reinstatement, and how GPCR signaling modulates these, remain unclear.

Studies using pharmacological manipulation of DA receptor signaling, lesions of DAergic regions and their forebrain targets, or measurement of DA neuron firing or nucleus accumbens (NAc) DA release show clear roles for DA circuits in reward salience, learning, valuation, and seeking (Berridge and Robinson, 1998; Everitt et al., 2008; Bromberg-Martin et al., 2010; Lüscher and Malenka, 2011; Lammel et al., 2014a; Keiflin and Janak, 2015; Pignatelli and Bonci, 2015; Hamid et al., 2016; Schultz, 2016; Saunders et al., 2018). VTA DA neuron-specific optogenetic stimulation experiments confirm reinforcing and conditioned motivation roles for DA neurons; conversely, optogenetic inhibition of VTA DA neurons is behaviorally avoided (Tsai et al., 2009; Adamantidis et al., 2011; Witten et al., 2011; Steinberg et al., 2013; Berrios et al., 2016). Specific dissections of VTA DA neuron behavioral functions also reveal marked functional heterogeneity, relating in part to efferent projection target and cotransmitter activity (Floresco and Magyar, 2006; Chaudhury et al., 2013; Lammel et al., 2014b; Trudeau et al., 2014; Barker et al., 2016; Tritsch et al., 2016; Edwards et al., 2017; Saunders et al., 2018). However, the roles for DA neurons in cocaine self-administration or relapse-like behaviors are poorly understood.

Considering that the vast majority of pharmacotherapies for psychiatric disorders act via modulation of GPCRs, it is imperative that we also understand how these receptors operate in vivo in defined cells, such as VTA DA neurons, to modify behavior. A great deal is known about the signaling and behavioral functions of endogenous GPCRs in DA neurons and circuits (Hearing et al., 2012; Meye et al., 2012, 2014; Gantz et al., 2013; Loweth et al., 2013; Fields and Margolis, 2015; Johnson and Lovinger, 2016; Wenzel and Cheer, 2018), but parsing the effects of pharmacological manipulations from those of endogenous receptor activity in vivo is challenging. Here, we use synthetic designer receptors exclusively activated by designer drugs (DREADDs) to artificially engage GPCR signaling "on demand," independent of activity at endogenous receptors, and specifically in VTA DA neurons. By directly (but not necessarily physiologically) activating these signaling cascades within neurons of interest using DREADDs, we can isolate their involvement in producing motivated behaviors related to addiction.

Here, we used this chemogenetic approach to probe the roles of VTA DA neurons, their main forebrain targets, and their GPCR-signaling mechanisms in cocaine intake and relapse. Taking advantage of the transient, reversible modulation offered by DREADDs to repeatedly and selectively manipulate DA neurons/ efferents during cocaine-seeking behaviors, we demonstrate that engaging $G_{i}$ and $G_{q}$ (but not $G_{s}$ ) signaling in VTA DA neurons causes task-dependent changes in drug seeking and cognition, depending on whether behavior was motivated by the reinforcing or priming effects of cocaine, cocaine-paired cues, or stress-like states.

\section{Materials and Methods}

Subjects. Male, hemizygous tyrosine hydroxylase (TH)::Cre transgenic rats (Witten et al., 2011; Mahler et al., 2014) and wild-type (WT) littermates $(n=134)$ were bred at Medical University of South Carolina (MUSC), University of California, Irvine (UCI), or Drexel University, from founders (mated to wild-type partners) provided by K. Deisseroth (Stanford University). They were housed in tub cages under a reverse $12 \mathrm{~h} \mathrm{light/dark} \mathrm{cycle,} \mathrm{with} \mathrm{free} \mathrm{access} \mathrm{to} \mathrm{food} \mathrm{and} \mathrm{water} \mathrm{at} \mathrm{all} \mathrm{times} \mathrm{(initial}$ surgical weight, 250-400 g). All procedures were approved by the MUSC, UCI, or Drexel University institutional animal care and use committees.
Viral constructs. Immediately after catheter implantation, $1 \mu \mathrm{l} / \mathrm{hemi-}$ sphere titer-matched adeno-associated virus 2 (AAV2) vectors containing a double-floxed, inverted open reading frame (DIO) sequence for the mCherry-tagged hM4Di ( $\mathrm{G}_{\mathrm{i}}$-coupled), hM3Dq ( $\mathrm{G}_{\mathrm{q}}$-coupled), or rM3Ds ( $\mathrm{G}_{\mathrm{s}}$-coupled) DREADDs, or mCherry control (hSyn-DIO-hM4DimCherry, hSyn-DIO-hM3Dq-mCherry, hSyn-DIO-rM3Ds-mCherry, hSynDIO-mCherry: University of North Carolina Vector Core or AddGene; key reinstatement and economic demand results were replicated with vectors from both sources) was pressure injected via Hamilton syringe (28 ga) or glass micropipette bilaterally into the ventromedial midbrain over 2 min ( $1 \mu \mathrm{l}$ retracted 5 min later) causing DREADD expression selectively in TH neurons of VTA (coordinates are relative to bregma: anteroposterior $(\mathrm{AP}),-5.5 ; \mathrm{ML}, \pm 0.8 ; \mathrm{DV},-8.15)$. WT rats were injected with one of the same DIO vectors $\left(\mathrm{G}_{\mathrm{q}}, n=9 ; \mathrm{G}_{\mathrm{s}}, n=8 ; \mathrm{G}_{\mathrm{i}}, n=8\right)$, although no expression was observed in any rat with vectors from either source. More than 4 weeks was allowed between virus injection and first clozapine $\mathrm{N}$-oxide (CNO) administration, during which time cocaine self-administration and extinction training occurred.

Surgical procedures. Intravenous catheter and intracranial surgeries have been described in detail previously (Mahler et al., 2013, 2014). Chronic jugular intravenous catheters were implanted exiting the back, then intracranial virus was injected stereotaxically in the same surgery. Cranial cannulae were implanted in NAc, medial prefrontal cortex (mPFC), or basolateral amygdala (BLA) in a separate surgery after initial $(8 \mathrm{~d})$ cocaine self-administration training ( $\sim 3$ weeks after the first surgery). After recovery, they completed 2 remaining self-administration days, followed by extinction, reinstatement tests, and food intake tests.

Drugs. Cocaine $\mathrm{HCl}$ was dissolved in $0.9 \%$ saline (intravenous selfadministration, $3.33 \mathrm{mg} / \mathrm{ml}$; intravenous behavioral economic (BE) selfadministration, $2.73 \mathrm{mg} / \mathrm{ml}$; cocaine prime, $10 \mathrm{mg} / \mathrm{ml}$ ). CNO was obtained from Tocris Bioscience or NIMH/NIDA Drug Supply Programs), dissolved in $5 \%$ DMSO in saline $(0,1,10 \mathrm{mg} / \mathrm{ml})$, and injected intraperitoneally $30 \mathrm{~min}$ before behavioral tests. Yohimbine $\mathrm{HCl}(\mathrm{YOH}$; Sigma-Aldrich) was dissolved in water $(2.5 \mathrm{mg} / \mathrm{ml})$ and injected intraperitoneally immediately after vehicle (Veh)/CNO injection. For intracranial injection, $\mathrm{CNO}$ was dissolved in $0.5 \%$ DMSO in artificial CSF (ACSF; $1 \mathrm{~mm} / 0.3 \mu \mathrm{l}$; total dose, $\sim 100 \mathrm{ng} /$ hemisphere) and microinjected 5 min before behavior.

Cocaine self-administration and extinction. The behavioral protocol used in these experiments is shown in Figure 1. Operant testing was conducted in Med Associates chambers. Rats received initial cocaine self-administration training until they self-administered $>10$ infusions/ daily $2 \mathrm{~h}$ session for $10 \mathrm{~d}$. Active lever presses yielded a $3.6 \mathrm{~s}$ infusion of 0.2 $\mathrm{mg} / 50 \mu \mathrm{l}$, i.v., cocaine and a concurrent tone/light cue, followed by a $20 \mathrm{~s}$ timeout period. Presses on the inactive lever had no consequences. Following self-administration training, rats received at least seven $2 \mathrm{~h}$ duration extinction training sessions, when lever presses yielded neither cues nor cocaine, which continued until the criterion was met $(<25$ active lever presses for $2 \mathrm{~d}$ ).

Reinstatement. Following extinction training, all rats underwent a series of $2 \mathrm{~h}$ reinstatement tests, each separated by $>2 \mathrm{~d}$ of re-extinction. Each reinstatement modality was tested after counterbalanced vehicle/ CNO $(1 / 10 \mathrm{mg} / \mathrm{kg})$ injections before moving on to the next reinstatement modality. The order of reinstatement modalities was fixed to minimize potential carryover effects of one type of reinstatement (e.g., yohimbine or cocaine prime) on others (e.g., cue reinstatement; Mahler et al., 2013). For cued reinstatement tests (all rats tested, $n=36$ ), active lever presses yielded cocaine-associated 3.6-s-duration cue presentations (followed by a $20 \mathrm{~s}$ timeout period signaled by extinguishing the houselight), but no cocaine. Inactive lever presses were recorded, but were inconsequential. For the CNO-induced reinstatement test ( $n=34 ; 2$ rats in an initial pilot group were not tested on this behavior), lever presses yielded neither cocaine nor cocaine cues, but were recorded. For primed reinstatement tests $(n=34 ; 2$ rats were removed from this and subsequent tests due to infection-related illness), cocaine (10 mg/kg, i.p.) was given immediately before the test, and lever presses were also inconsequential. For yohimbine plus cue reinstatement tests, rats $(n=29 ; 5$ rats in the initial pilot cohorts were not tested, and 2 rats were excluded for illness) received the pharmacological stressor yohimbine $(2.5 \mathrm{mg} / \mathrm{kg}$, i.p.; 


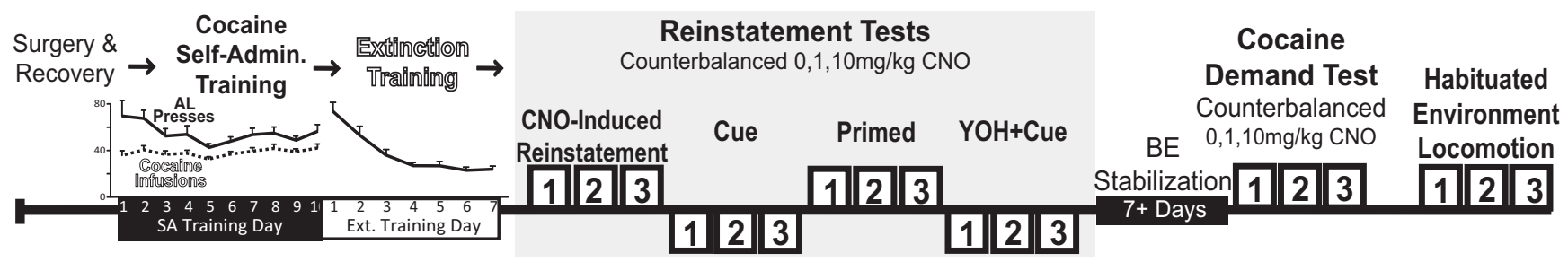

Figure 1. Behavioral testing timeline: following surgery and recovery, $\mathrm{G}_{q^{-}}, \mathrm{G}_{\mathrm{s}}-\mathrm{G}_{\mathrm{i}}-\mathrm{DREADD}$ rats and WT controls were trained to self-administer cocaine plus a tone/light cue over 10 daily $2 \mathrm{~h}$ sessions, then extinguished over more than seven additional sessions. In a repeated-measures design, we examined the effects of counterbalanced injections of CNO $(0,1,10 \mathrm{mg} / \mathrm{kg})$ on cocaine seeking in a CNO-induced reinstatement test (no cues/cocaine), during reinstatement elicited by cocaine cues, cocaine priming injection, or yohimbine (YOH) plus cocaine cues, on a test of cocaine behavioral economic (BE) demand, and on locomotor activity in a habituated environment.

$5 \mathrm{~min}$ before $\mathrm{CNO} / \mathrm{Veh}, 35 \mathrm{~min}$ before test), and active lever presses yielded delivery of previously cocaine-associated cues, followed by a $20 \mathrm{~s}$ signaled timeout. After each reinstatement test, rats were given more than two extinction retraining sessions until they returned to the extinction criterion.

Cocaine demand elasticity. Across species, motivation for a reward can be measured via analysis of demand elasticity or the sensitivity of reward consumption to increasing price (Bickel et al., 1990; Hursh, 1993). The within-session cocaine BE paradigm is a useful behavioral tool for examining the effects of acute neural manipulations in rats on economic demand (España et al., 2010; Oleson et al., 2011; Bentzley et al., 2013, 2014). Rats $(n=36)$ were trained to self-administer cocaine under a withinsession cocaine demand protocol, as described previously (España et al., 2010; Oleson et al., 2011; Bentzley et al., 2013). On an fixed ratio 1 (FR1) schedule, rats self-administered cocaine at doses that decreased in $10 \mathrm{~min}$ blocks over the $110 \mathrm{~min}$ session $(383.5,215.6,121.3,68.2,38.3,21.6,12.1$, $6.8,3.8,2.2$, and $1.2 \mu \mathrm{g}$ per infusion), requiring increasing effort across the session to maintain the preferred brain cocaine concentration. After every session, a demand curve was fit to the consumption data from each rat using an exponential demand equation (Hursh, 1993; Bentzley et al., 2013) to determine economic demand for cocaine as previously described (Bentzley et al., 2013).

The values of $\alpha$ and $Q_{0}$ in Equation 1 were calculated using a novel approach that we developed specifically for data acquired via the withinsession cocaine BE paradigm used herein (Bentzley et al., 2013). This approach was set to model cocaine demand that occurs when brain cocaine concentration is stable, such that a rapidly changing brain cocaine concentration does not influence the measures of cocaine demand. See the study by Bentzley et al. (2013) for a complete discussion for the rationale and details of this approach. Briefly, a custom Excel (Microsoft) macro was used to determine and remove data points associated with rapidly changing brain cocaine concentrations over time. A demand curve computed using the exponential demand equation (Eq. 1) was then fit to the remaining cocaine consumption data (Hursh and Silberberg, 2008).

$$
\ln Q=\ln Q_{0}+k\left(e^{-a Q_{0} C}-1\right) .
$$

The values $\alpha$ and $Q_{0}$ in Equation 1 were then determined via an automated, iterative process performed by a custom Excel macro, because Equation 1 cannot be solved algebraically. The macro manipulated the values of $\alpha$ and $Q_{0}$ to minimize the residual sum of squares (i.e., the square of the difference between the experimentally measured demand and the demand predicted by Equation 1 was found for each price and then summed across all prices). The parameter $k$ in Equation 1 represents the range of the consumption data in $\log _{\mathrm{e}}$ units and was held constant at a value of 7.368 (3.2 in $\log _{10}$ units) across all animals. This value of $k$ was chosen based on the maximum observed range of consumption.

Using this behavioral economic approach, effects of neural manipulations on (1) preferred cocaine blood levels under low-effort conditions (free consumption; $Q_{0}$ ), and (2) the sensitivity of demand to price (demand elasticity; $\alpha$ ) can be derived from data in a single session. Rats were trained for a minimum of $5 \mathrm{~d}$, until $<25 \%$ variability of the $\alpha$ parameter in the last three sessions. Values for $\alpha$ and $Q_{0}$ were calculated as a percentage of stable performance on the prior 3 drug-free training days.
Most rats were previously tested on self-administration, extinction, and reinstatement $\left(\mathrm{G}_{\mathrm{q}}, n=6 ; \mathrm{G}_{\mathrm{s}}, n=3 ; \mathrm{G}_{\mathrm{i}}, n=8\right.$; WT, $\left.n=8\right)$, although an initial cohort did not undergo demand analysis $\left(G_{s}, n=8\right)$, or lost catheter patency during extinction/reinstatement testing $\left(\mathrm{G}_{\mathrm{i}}, n=1 ; \mathrm{G}_{\mathrm{q}}\right.$, $n=1)$. Therefore, additional rats were added to each DREADD group, to replicate the effects in rats without prior extinction/reinstatement experience $\left(\mathrm{G}_{\mathrm{i}}, n=6 ; \mathrm{G}_{\mathrm{q}}, n=1 ; \mathrm{G}_{\mathrm{s}}, n=4\right)$.

Locomotion. Following self-administration and reinstatement testing, a subset of rats previously tested as described above $\left(\mathrm{G}_{\mathrm{q}}, n=6 ; \mathrm{G}_{\mathrm{s}}, n=6\right.$; $\mathrm{G}_{\mathrm{i}}, n=5$; WT, $n=7$ ) were habituated for two daily $2 \mathrm{~h}$ sessions to a locomotor testing chamber $(40 \times 40 \times 30 \mathrm{~cm})$, with clear plastic sides, corncob bedding, and photobeam arrays to measure horizontal and vertical activity, then tested for $\mathrm{CNO} / \mathrm{Veh}$ effects in $2 \mathrm{~h}$ sessions on separate days.

Food intake. Effects of intracranial vehicle or $\mathrm{CNO}(1 \mathrm{mM})$ injections into $\operatorname{mPFC}(n=10,0.3 \mu \mathrm{l}), \mathrm{NAc}(n=11,0.5 \mu \mathrm{l})$, or BLA $(n=7,0.5 \mu \mathrm{l})$ on spontaneous chow intake were measured on two $2 \mathrm{~h}$ sessions held $48 \mathrm{~h}$ apart, following self-administration, extinction, and reinstatement tests (four prior microinjections before testing food intake). They were first habituated for two $2 \mathrm{~h}$ sessions to the same clear plastic tub cage with corncob bedding, preweighed chow on the floor, and a water bottle. Chow intake was quantified by comparing food weight before and after these sessions.

Colocalization of mCherry and TH in VTA. To confirm DREADD expression in VTA DA neurons, costaining for mCherry and TH was performed on VTA sections from cocaine-experienced rats behaviorally tested above $(n=30)$. The $40 \mu \mathrm{m}$ sections were blocked in 3\% normal donkey serum (NDS), then incubated in rabbit anti DS Red to label mCherry (1:1000; catalog \#632496, Clontech) and mouse anti TH (1:1000; catalog \#22941, Immunostar) for $16 \mathrm{~h}$ at room temperature (RT). Sections were washed, then incubated in Alexa Fluor donkey anti-rabbit 488 and donkey anti-mouse 594 antibodies (both 1:500; Jackson ImmunoResearch) for $4 \mathrm{~h}$. Sections were coverslipped and imaged on a Leica epifluorescent microscope with StereoInvestigator software (MicroBrightfield). Images of the entire VTA and substantia nigra (SN) were obtained from three planes in the $z$-axis at $10 \times$ magnification, stitched together using the StereoInvestigator virtual slice module, and collapsed into a flat maximum projection image of ventral midbrain for quantification by an observer blind to experimental condition. The percentage of mCherry neurons with or without somatic TH expression (to determine specificity), and $\mathrm{TH}(+)$ neurons with or without coexpression of mCherry (to determine penetrance), were quantified bilaterally within the entire VTA and $\mathrm{SN}$ on one slice per rat (5.3 to $5.6 \mathrm{~mm}$ caudal of bregma; $\mathrm{G}_{\mathrm{q}}, n=8 ; \mathrm{G}_{\mathrm{s}}, n=8 ; \mathrm{G}_{\mathrm{i}}, n=8$; mCherry, $n=6$ ).

Fos expression in VTA DA neurons. To verify DREADD stimulation of VTA DA neurons, we examined Fos expression in VTA TH $(+)$ neurons in a subset of behaviorally tested rats $\left(\mathrm{G}_{\mathrm{q}} \mathrm{Veh} / 10 \mathrm{CNO}, n=2 / 3 ; \mathrm{G}_{\mathrm{s}}, n=\right.$ $2 / 2 ; \mathrm{G}_{\mathrm{i}}, n=2 / 2$ ). Animals were given vehicle or CNO intraperitoneally, left undisturbed in their home cages for $180 \mathrm{~min}$, then perfused. Coronal $40 \mu \mathrm{m}$ sections were blocked in $3 \%$ normal donkey serum, then incubated in rabbit anti c-Fos (1:1000; ABE457, Millipore) and mouse anti-TH for $16 \mathrm{~h}$ at RT in phosphate buffered saline $(0.01 \mathrm{M})$ with Triton $\mathrm{X}(0.3 \%)$. Sections were washed, then incubated in Alexa Fluor donkey anti-rabbit 488 and donkey anti-mouse 594 (1:500 of each; catalog $\# 715585150$, JacksonImmunoresearch) for $4 \mathrm{~h}$. Sections were imaged at 
$20 \times$, and Fos was quantified in $\mathrm{TH}(+)$ and $\mathrm{TH}(-)$ cells in three bilateral sections/rat at approximately $-5.2,-5.5$, and -5.8 caudal of bregma. All $\mathrm{TH}(+)$ and Fos $(+)$ cells were counted, and the expression of Fos in $\mathrm{TH}(+)$ neurons of VTA and SN was quantified.

In vitro electrophysiology. Brain slices were prepared as described previously (Riegel and Williams, 2008; Williams et al., 2014) from behaviorally tested TH:Cre rats with mCherry-tagged $\mathrm{G}_{\mathrm{i}^{-}}, \mathrm{G}_{\mathrm{q}^{-}}$, or $\mathrm{G}_{\mathrm{s}}$-coupled DREADDs, as described above. Briefly, brains were removed following rapid decapitation and placed in a vibratome (Leica) containing ice-cold ACSF solution (126 mM NaCl, $2.5 \mathrm{~mm} \mathrm{KCl}, 1.2 \mathrm{~mm} \mathrm{MgCl} 2,1.4 \mathrm{~mm}$ $\mathrm{NaH}_{2} \mathrm{PO}_{4}, 25 \mathrm{~mm} \mathrm{NaHCO} 3,11 \mathrm{~mm}$-glucose, $0.4 \mathrm{~mm}$ ascorbate, and $0.01 \mathrm{~mm}$ MK801). Horizontal slices $(220 \mathrm{~m})$ containing the VTA were prepared and stored in oxygenated ACSF containing $0.01 \mathrm{~mm}$ MK801 $\left(95 \% \mathrm{O}_{2}-5 \% \mathrm{CO}_{2} ; 34^{\circ} \mathrm{C}\right)$ until recording. During recording, sections were perfused at a flow rate of $2 \mathrm{ml} / \mathrm{min}$ with oxygenated ACSF, at $33^{\circ} \mathrm{C}$. DA neurons residing $150 \mu \mathrm{m}$ from the lateral or medial side of the terminal nucleus of the accessory optic tract were visualized with infrared differential interference contrast optics to confirm mCherry fluorescence indicative of DREADD expression. Recordings were made using Multiclamp 700B Amplifiers (Molecular Devices) and collected with AxoGraph X (AxoGraph), filtered at $1-2 \mathrm{kHz}$, and digitized at $2-5 \mathrm{kHz}$. Spontaneous AP firing was monitored using either whole-cell currentclamp or cell-attached recording configurations with 1-2 $\mathrm{M}$ pipettes filled with $115 \mathrm{~mm}$ K-methylsulfate, $20 \mathrm{~mm} \mathrm{NaCl}, 1.5 \mathrm{~mm} \mathrm{MgCl} 2,2.5 \mathrm{~mm}$ HEPES, 2 mм ATP, 0.3 mм GTP, and 0.1 mм EGTA, pH 7.3 and 265-270 $\mathrm{mOsm}$. Firing rates were evaluated in the cell-attached configuration. Only neurons displaying stable pacemaker firing (1-5 Hz) for the duration of the experiment were included for analysis of firing rates in response to $\mathrm{CNO}$ ( $5 \mu \mathrm{m}$; washed onto slices following stable baseline recordings).

In vitro cyclic voltammetry. Separate, behaviorally naive TH:Cre rats $\left(\mathrm{G}_{\mathrm{q}}, n=8 ; \mathrm{G}_{\mathrm{s}}, n=8 ; \mathrm{G}_{\mathrm{i}}, n=6\right.$; WT, $\left.n=8\right)$ were killed, and their brains were rapidly removed and prepared as previously described (Brodnik and España, 2015). Coronal slices $(400 \mu \mathrm{m})$ of the striatum were maintained at $32^{\circ} \mathrm{C}$ in oxygen-perfused $\left(95 \% \mathrm{O}_{2}-5 \% \mathrm{CO}_{2}\right)$ ACSF, which consisted of the following (in mM): $\mathrm{NaCl} 126, \mathrm{NaHCO}_{3} 25$, D-glucose $11, \mathrm{KCl}$ 2.5, $\mathrm{CaCl}_{2} 2.4, \mathrm{MgCl}_{2} 1.2, \mathrm{NaH}_{2} \mathrm{PO}_{4} 1.2$, and L-ascorbic acid 0.4, with $\mathrm{pH}$ adjusted to 7.4. A carbon fiber microelectrode (150-200 $\mu \mathrm{m}$ length $\times 7$ $\mu \mathrm{m}$ diameter) and a bipolar stimulating electrode (Plastics One) were placed in the NAc. The carbon fiber electrode potential was linearly scanned as a triangular waveform from -0.4 to $1.2 \mathrm{~V}$ and back to $-0.4 \mathrm{~V}$ (Ag vs $\mathrm{AgCl}$ ) using a scan rate of $400 \mathrm{~V} / \mathrm{s}$. Cyclic voltammograms were recorded every $100 \mathrm{~ms}$ by means of a potentiostat (Dagan) using Demon Voltammetry and Analysis (Yorgason et al., 2011). Extracellular concentrations of DA were assessed by comparing the current at the peak oxidation potential for DA with electrode calibrations with $3 \mu \mathrm{m}$ DA. DA release was evoked every $5 \mathrm{~min}$ by a single $4 \mathrm{~ms}$ stimulation (monophasic, $400 \mu \mathrm{A})$, until three stable baseline responses were acquired $(<10 \%$ variation) before $\mathrm{CNO}$ was added to the perfusion medium. Following the application of $\mathrm{CNO}(5 \mu \mathrm{M})$, we evaluated DA release to both a single pulse and multiple pulses (five pulses at $5-40 \mathrm{~Hz}$ ).

Anesthetized electrophysiology. In separate rats without cocaine experience $\left(\mathrm{G}_{\mathrm{q}}, n=8 ; \mathrm{G}_{\mathrm{s}}, n=2 ; \mathrm{G}_{\mathrm{i}}, n=8 ;\right.$ mCherry, $\left.n=4\right)$, we performed extracellular, anesthetized recordings of single units in VTA, before and after intraperitoneal injection of CNO $(10 \mathrm{mg} / \mathrm{kg})$. Animals were anesthetized with $2-3 \%$ isoflurane and maintained at a rectal temperature of $36-38^{\circ} \mathrm{C}$ throughout the recordings. Affixed in a stereotaxic instrument, craniotomies were prepared dorsal to VTA, exposing the brain surface from 0.5 to $1.3 \mathrm{~mm}$ lateral of midline and $4.0-7.0$ caudal of bregma. Following previously described procedures (Georges and Aston-Jones, 2002; Kaufling and Aston-Jones, 2015), glass micropipettes (filled with $2 \%$ pontamine sky blue in $0.5 \mathrm{M}$ sodium acetate; tip internal diameter, $\sim 1$ $\mu \mathrm{m}$; impedance, $6-12 \mathrm{~m} \Omega$ ) were advanced through VTA between the following coordinates (relative to bregma): AP, -5.1 to 6.1 ; ML, $\pm 0.5-$ 1.1 ; DV,-7.0 to 9.0. They were implemented in a consistent grid-based sampling method (Grace et al., 2007) with $>200 \mu \mathrm{m}$ between consecutive tracks and $<400 \mu \mathrm{m}$ between at least one pre-CNO and post-CNO track within a given animal. Signals were amplified and filtered $(1000 \times$ gain, $50-4000 \mathrm{~Hz}$ bandpass) using conventional electronics, sent to an audio monitor and oscilloscope for on-line monitoring (high pass, 50 $\mathrm{Hz}$; low pass, $16 \mathrm{KHz}$ ), and digitized and recorded via CED 1401 and Spike 2 software (Cambridge Electronic Design). When single-unit activity was detected by monitoring audio and oscilloscope outputs, we advanced slowly upon the cell until it was isolated at a signal/noise ratio of $\sim 2: 1$ or better. All isolated units $(n=400)$ were recorded for $120 \mathrm{~s}$, then the electrode was lowered $200 \mu \mathrm{m}$, and sampling resumed. After sampling two to nine tracks per rat, we injected CNO (10 mg/kg, i.p.), and from 30 to $210 \mathrm{~min}$ later, we sampled an additional one to four tracks per rat (a maximum $3 \mathrm{~h}$ after $\mathrm{CNO}$ injection). Pontamine sky blue was deposited electrophoretically at the end of the last track each day before perfusion, and recording sites within VTA were reconstructed. Cells were classified as type 1 ("Classic DA-like") or type 2, based on conventional criteria described in detail previously (Grace and Bunney, 1984; Luo et al., 2008; Ungless and Grace, 2012). The mean number of type 1 and 2 cells encountered per track was compared before and after CNO.

Colocalization of mCherry and TH in mPFC and NAc. We examined colocalization of TH (a putative marker of DAergic axonal microdomains; Zhang et al., 2015) with mCherry in a subset of the cocaineexperienced rats described above $(n=10)$. We imaged areas of prelimbic cortex (layers 5 and 6) and NAcCore (immediately dorsal and medial of the anterior commissure) from DREADD-infected rats $\left(\mathrm{G}_{\mathrm{q}}, n=4 ; \mathrm{G}_{\mathrm{s}}\right.$, $\left.n=2 ; \mathrm{G}_{\mathrm{i}}, n=4\right)$. Z-series confocal microscopy datasets were acquired with the exact same parameters for PFC and NAc sections. Images were taken through the entirety of the tissue slice for both regions using a $63 \times$ objective with a voxel size of $0.24 \times 0.24 \times 0.504$. Two $z$-series datasets were taken for each animal, one on each hemisphere. Values obtained for these two datasets were averaged to create an animal average for each brain region investigated. All laser and gain settings were kept constant between animals and between brain regions. Once datasets were collected they were deconvolved using autoquant deblur and imported into Imaris (Bitplane). Once in Imaris, threshold values for colocalization analysis of DREADD and TH signals were automatically set by the Imaris software colocalization module. Values set by Imaris for colocalization signal intensity thresholds were not significantly different for DREADD (red) or $\mathrm{TH}$ (green) signals in either the mPFC or NAc, nor did mCherry expression differ between DREADD groups.

Experimental design and statistical analysis. For behavioral and colocalization, and Fos analyses, mixed-model and repeated-measures ANOVAs with Bonferroni-corrected post hoc $t$ test, or paired-samples $t$ tests were used as appropriate. When data were not normally distributed, nonparametric statistics [Mann-Whitney $U$ (MWU) test; Friedman's test] or Greenhouse-Geisser degrees of freedom corrections were used. Cocaine economic demand was stabilized for $>2 \mathrm{~d}$ before each test, then the change from this stable baseline after vehicle or CNO administration was computed and analyzed with repeated-measures ANOVA. Pearson correlations were computed to examine the relationship between locomotor and reinstatement effects of $\mathrm{CNO}$ (change from vehicle day horizontal locomotion and cue-induced cocaine seeking after $10 \mathrm{mg} / \mathrm{kg}$ $\mathrm{CNO}$ ). For in vitro physiology, spontaneous firing rate in the $30 \mathrm{~s}$ before or after $\mathrm{CNO}$ bath application ( $5 \mu \mathrm{M}, 4-6 \mathrm{~min}$ ) was measured in one to two mCherry fluorescing VTA neurons per rat. For in vitro voltammetry, evoked DA was computed as a percentage of pre-CNO baseline, and a mixed-model ANOVA determined the effects DREADD group $\times$ stimulation frequency. For in vivo physiology, the mean number of type 1 and 2 neurons per recording track per rat, before versus after $\mathrm{CNO}$, were compared using unpaired $t$ tests in each DREADD group. All experiments were conducted in at least two cohorts, boosting confidence in the reliability of the reported effects.

\section{Results \\ Validation of DA DREADD manipulations}

In male TH:Cre rats or their WT littermates $(250-400 \mathrm{~g})$ bred at MUSC, UCI, or Drexel University, we targeted injections of Credependent DIO vectors to VTA, causing the expression of mCherry-tagged $\mathrm{G}_{\mathrm{q}^{-}}, \mathrm{G}_{\mathrm{s}^{-}}$, or $\mathrm{G}_{\mathrm{i}}$-coupled DREADDs; mCherry in VTA DA neurons in TH:Cre rats; or no DREADD expression in WT rats (Fig. 2a). Expression of the DREADD-fused mCherry tag 

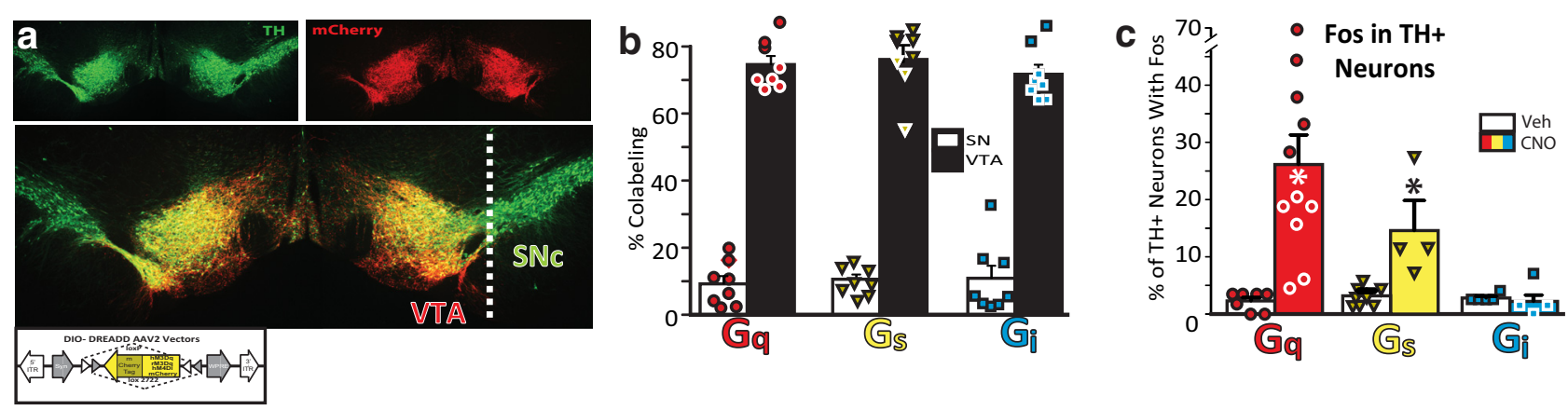

\section{d In Vitro Firing Rate}

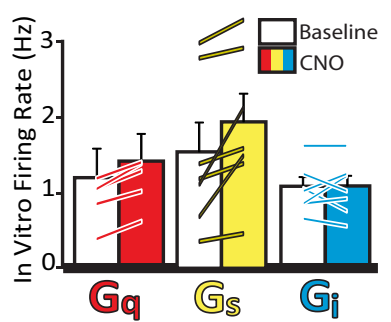

e Change from Baseline In Vitro Firing

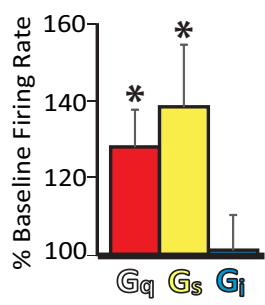

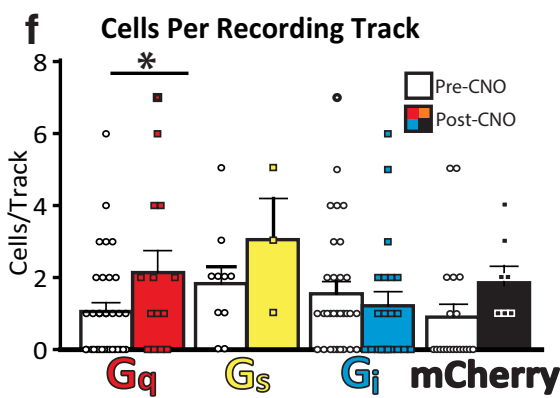

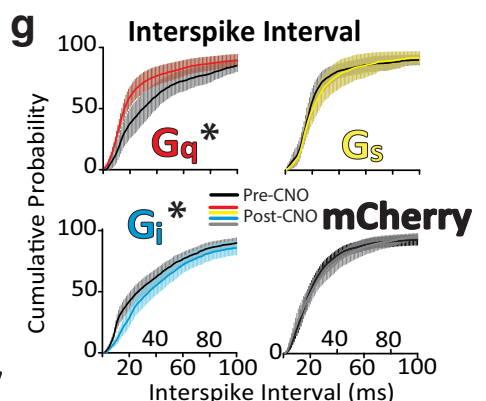

Figure 2. DREADD expression and function in VTA DA Neurons. $\boldsymbol{a}$, Midbrain TH staining (green) and mCherry-tagged DREADD expression (red) in VTA is shown, with yellow indicating colabeling. Inset shows schematic of AAV DIO-DREADD vectors used. $\boldsymbol{b}$, Percentage of midbrain TH + cells located within borders of SN (white bars), or VTA (black bars) that coexpress mCherry-tagged DREADDs. Individual rat data shown with red diamond $\left(G_{q}\right)$, yellow triangle $\left(G_{s}\right)$, or blue square $\left(G_{i}\right)$ symbols. $c$, Percentage of TH+ VTA neurons expressing Fos after Veh or $\mathrm{CNO}(10 \mathrm{mg} / \mathrm{kg})$ in $G_{q^{-}}$, $G_{s^{-}}$, or $\mathrm{G}_{\mathrm{i}}$-coupled DREADD rats (individual rat data represented with symbols on top of bars). $\boldsymbol{d}$, Firing rates are depicted for baseline and post-CNO periods, and individual cells are depicted with lines. $\boldsymbol{e}$, CNO increases the mean (SEM) firing rate of VTA DREADD + neurons in vitro, relative to baseline firing. $\boldsymbol{f}$, In anesthetized rats with $\mathrm{G}_{\mathrm{q}}$ DREADDs, more type 1 cells were encountered per electrophysiological recording track after $10 \mathrm{mg} / \mathrm{kg}$ CNO injection (colored bars, symbols) than before CNO injection (white bars, symbols). No significant effects on population activity were observed after $\mathrm{CNO}$ injection in the $\mathrm{G}_{\mathrm{s}^{\prime}} \mathrm{G}_{\mathrm{i}}$, or mCherry groups. $\boldsymbol{g}$, Interspike interval before CNO injection (black lines, error bars indicate the SEM) and after $10 \mathrm{mg} / \mathrm{kg}$, i.p., $\mathrm{CNO}$ injection (red, $\mathrm{G}_{\mathrm{q}} ;$ yellow, $\mathrm{G}_{\mathrm{s}} ;$ blue, $\mathrm{G}_{\mathrm{i}}$; black, $\mathrm{mCherry).}{ }^{*} p<0.05$.

was highly specific to VTA/medial SN TH $(+)$ neurons in TH:Cre rats, as previously reported (Witten et al., 2011; Mahler et al., 2014 ), with $>97 \%$ coexpression of $\mathrm{TH}$ in mCherry + cell bodies in ventral midbrain (Tye et al., 2013; Mahler et al., 2014). Overall, $>70 \%$ of VTA $\mathrm{TH}(+)$ neurons coexpressed DREADDs, while only $\sim 10 \%$ of lateral SN DA neurons expressed DREADDs (Fig. $2 b)$. DREADD expression spanned nearly the entire rostrocaudal axis of VTA in these animals, typically with sparser expression in medial than in lateral aspects of VTA, and extended into the most medial aspects of SN pars compacta. No significant differences in VTA infection rate of cell bodies was seen among $\mathrm{G}_{\mathrm{i}^{-}}, \mathrm{G}_{\mathrm{s}}{ }^{-}$, and $\mathrm{G}_{\mathrm{q}}$-coupled vectors (no effect of DREADD group on colocalization percentage: $F_{(2,23)}=0.576, p=0.57$; Fig. $\left.2 b\right)$, though we note that the infected neurons are not necessarily identical populations across vectors. No DREADD/mCherry expression was seen in WT control rats.

As expected, CNO $(10 \mathrm{mg} / \mathrm{kg})$ markedly induced Fos in $\mathrm{TH}(+)$ VTA neurons of rats expressing $\mathrm{G}_{\mathrm{q}}$, but not $\mathrm{G}_{\mathrm{i}}$ DREADDs $\left(\right.$ DREADD group $\times$ Tx interaction; $F_{(2,35)}=3.4, p=0.046$; Fig. $2 c)$. Acute stimulation of VTA DA neurons with CNO $(10 \mathrm{mg} / \mathrm{kg})$ in $\mathrm{G}_{\mathrm{q}}$ rats increased over vehicle the percentage of $\mathrm{TH}(+)$ VTA neurons that expressed Fos (main effect of Tx in $\mathrm{G}_{\mathrm{q}}$ rats; MWU test, $p=0.001$ ), whereas Fos in TH( - ) VTA neurons was concurrently suppressed (MWU test, $p=0.03$ ). In a small sample of $\mathrm{G}_{\mathrm{s}}$ rats, $\mathrm{CNO}(n=4)$ similarly increased Fos in $\mathrm{TH}(+)$ neurons over vehicle controls ( $n=8$; Tx effect; MWU test, $p=0.004)$, but Fos expression in $\mathrm{TH}(-)$ VTA neurons was not altered (MWU test, $p=0.68$, n.s.). Fos was not significantly reduced by $\mathrm{CNO}$ in $\mathrm{G}_{\mathrm{i}}$ rats $[\mathrm{TH}(+)$ neurons Tx effect: MWU test, $p=0.26$, n.s.; $\mathrm{TH}(-)$ neurons: $p=1.0$, n.s.; Fig. $2 c$ ], likely because Fos expres- sion was already very low in control rats treated with vehicle in their home cage.

To further characterize DREADD modulation of DA cell activity, we recorded the effects of $\mathrm{CNO}$ on firing in vitro and in vivo. First, horizontal VTA slices were prepared as described previously (Williams et al., 2014), and DREADD-expressing $(\mathrm{mCherry}+)$ cells were sampled in the cell-attached configuration to record spontaneous firing rates. We detected no difference in the basal firing rates of DA neurons expressing $G_{q}, G_{s}$, or $\mathrm{G}_{\mathrm{i}}$ (in hertz: $F_{(2,16)}=0.658, p=0.531$ ). After washing on $\mathrm{CNO}$ $(5 \mu \mathrm{M})$, both $\mathrm{G}_{\mathrm{q}}$ - and $\mathrm{G}_{\mathrm{s}}$-expressing $\mathrm{DA}$ neurons increased firing compared with pre-CNO baseline $\left(\mathrm{G}_{\mathrm{q}}: t_{(6)}=2.9, p=0.028 ; \mathrm{G}_{\mathrm{s}}\right.$ : $\left.t_{(4)}=5.4, p=0.006\right)$, but CNO did not affect spontaneous firing in slices from $\mathrm{G}_{\mathrm{i}}$ rats $\left(t_{(6)}=0.04, p=0.968\right.$; Fig. $\left.2 d, e\right)$.

We next examined whether $\mathrm{CNO}$ affects the number of spontaneously active VTA cells recorded in vivo in isoflurane-anesthetized rats. Using a systematic grid-based cells/track sampling method (Lodge and Grace, 2006), we performed preliminary analyses of all well-isolated cells encountered in the $3.5 \mathrm{~h}$ before and after intraperitoneal CNO injections (pre-CNO, $n=257$; post-CNO, $n=143$ ). We analyzed data from the two most commonly sampled types of neurons encountered in VTA: type 1 neurons with a $>2 \mathrm{~ms}$ waveform and $\mathrm{a}<10 \mathrm{~Hz}$ firing rate, which are likely to be a subset of DAergic neurons (Ungless and Grace, 2012; $n=200$ ), and type 2 neurons with $<2 \mathrm{~ms}$ waveforms, a $>10 \mathrm{~Hz}$ firing rate, and an uncharacterized phenotype $(n=200)$. CNO $(10 \mathrm{mg} / \mathrm{kg})$ did not affect the numbers of type 1 or type 2 cells encountered in $\mathrm{G}_{\mathrm{i}}, \mathrm{G}_{\mathrm{s}}$, or mCherry rats $\left(\mathrm{G}_{\mathrm{i}}: F_{(1,49)}=0.3, p=0.57 ; \mathrm{G}_{\mathrm{s}}: F_{(1,12)}=\right.$ $1.3, p=0.27$; mCherry: $F_{(1,26)}=3.1, p=0.09$; type $2: F$ values $<0.73$, $p$ values $>0.4$ ), but did increase the prevalence of active 
type 1 cells in $\mathrm{G}_{\mathrm{q}}$ rats $\left(F_{(1,46)}=4.0, p=0.05\right)$ without affecting type 2 prevalence $\left(F_{(1,46)}=0.72, p=0.790\right)$. This indicates that $\mathrm{G}_{\mathrm{q}}$ stimulation induced activity in a subset of otherwise quiescent VTA DA cells (Fig. $2 f$ ). We also examined the effects of DREADD manipulations on firing rates of VTA DA neurons and found, relative to interspike intervals (ISIs) before $\mathrm{CNO}, \mathrm{CNO}$ decreased ISIs in $\mathrm{G}_{\mathrm{q}}$ rats, increased ISIs in $\mathrm{G}_{\mathrm{i}}$ rats, and did not alter ISIs in $\mathrm{G}_{\mathrm{s}}$ or WT rats $\left(\mathrm{G}_{\mathrm{q}}: F_{(1,2000)}=125.5, p<0.0001 ; \mathrm{G}_{\mathrm{i}}: F_{(1,3600)}=57.45\right.$, $p<0.001 ; \mathrm{G}_{\mathrm{s}}: F_{(1,800)}=1.85, p=0.17$; mCherry: $F_{(1,1600)}=2.03$, $p=0.15$; Fig. $2 g$ ). Although the sample sizes in this experiment are small, results are consistent with those of other assays of DREADD efficacy in modulating DA neuron activity. Having validated chemogenetic modulation of DA neurons, we next examined the effects of these manipulations on cocaine-seeking behaviors.

\section{Behavioral effects of DA neuron DREADD manipulations}

$D A$ neuron roles in cocaine reinstatement

Addiction is a chronic relapsing disorder, so we examined chemogenetic DA neuron manipulation effects in a rat model of relapse elicited by cocaine cues, priming, or stress (Bossert et al., 2013; Martin-Fardon and Weiss, 2013). Although these stimuli elicit similar levels of drug-seeking behavior, the neural substrates underlying each type of reinstatement are distinguishable (Stewart, 2000; Kalivas and McFarland, 2003; Mahler et al., 2014; Farrell et al., 2018). Therefore, we sought to determine the necessity and sufficiency of VTA DA neurons for reinstatement of cocaine seeking.

After $10 \mathrm{~d}$ of cocaine self-administration followed by extinction training, we queried the effects of DA neuron stimulation or inhibition on reinstatement behavior (i.e., pressing the previously cocainedelivering active lever) due to (1) DA neuron manipulation alone (CNO-induced reinstatement in an extinguished context without cues or cocaine), (2) cue-induced reinstatement (active lever response-contingent cocaine cues, but no cocaine), (3) cocaineprimed reinstatement $(10 \mathrm{mg} / \mathrm{kg}$, i.p., cocaine before test, no cues or additional cocaine), and (4) pharmacological stress enhancement of cued reinstatement [ $2.5 \mathrm{mg} / \mathrm{kg}$, i.p., $\mathrm{YOH}$, with response-contingent cues but no cocaine]. Each reinstatement modality was tested three times in each rat, each $30 \mathrm{~min}$ after counterbalanced injections of $\mathrm{CNO}(0,1$, and $10 \mathrm{mg} / \mathrm{kg})$.

$G_{q} D A$ neuron stimulation dramatically increased reinstatement Under all reinstatement conditions examined, CNO robustly increased cocaine-seeking behavior up to $2000 \%$ of vehicle day levels in $\mathrm{G}_{\mathrm{q}}$ rats (effect of Tx on CNO-induced reinstatement: $F_{(2,12)}=4.8, p=0.03$; on cued reinstatement: $F_{(2,12)}=6.1, p=$ 0.02 ; on primed reinstatement: $F_{(2,12)}=7.1, p=0.009$; on $\mathrm{YOH}$ reinstatement: $F_{(2,12)}=4.1, p=0.045$; Fig. $3 a$, and Fig. 3-1a, available at https://doi.org/10.1523/JNEUROSCI.0537-18.2018. f3-1). CNO effects were specific to the active lever (as opposed to the always inert inactive lever) in the CNO-induced reinstatement test $\left(\mathrm{Tx} \times\right.$ lever interaction: $\left.F_{(2,12)}=6.2, p=0.014\right)$ and trended toward such specificity in cued reinstatement $\left(F_{(2,12)}=\right.$ $3.4, p=0.068)$. CNO increased pressing on both levers equivalently on cocaine-primed (no interaction; $F_{(2,12)}=1.7, p=0.23$ ) and $\mathrm{YOH}$ reinstatement tests $\left(F_{(2,12)}=2.2, p=0.158\right)$. CNO effects on active lever pressing did not statistically differ by $\mathrm{CNO}$ dose (change from vehicle day active lever pressing after 1 or 10 $\mathrm{mg} / \mathrm{kg} \mathrm{CNO}$; $t$ values $<1.55$, $p$ values $<0.171$ ), nor did effects dissipate over the $2 \mathrm{~h}$ test (no dose $\times$ time interaction: $F_{(6,36)}$ values $<2.4$, n.s.; Fig. $4 a)$.
Modest effects of $G_{s} D A$ neuron stimulation on reinstatement In contrast to $\mathrm{G}_{\mathrm{q}}$ rats, $\mathrm{CNO}$ did not robustly enhance cocaine seeking in rats with equivalent expression of $G_{s}$ DREADDs in VTA DA neurons (Fig. $3 b$ ). Cued reinstatement was marginally increased by CNO (main effect of Tx: $F_{(2,20)}=4.780, p=0.02$ ), but post hoc analysis of $\mathrm{CNO}$ dose effects on active lever pressing failed to meet the Bonferroni-corrected threshold $(1 \mathrm{mg} / \mathrm{kg}$ : $t_{(10)}=2.469, p=0.033$; significance threshold: $\left.p<0.025\right)$. However, cue-induced active lever pressing was increased by $1 \mathrm{mg} / \mathrm{kg}$ (not $10 \mathrm{mg} / \mathrm{kg}$ ) CNO for the first $30 \mathrm{~min}$ of the $2 \mathrm{~h}$ session, after which cocaine seeking returned to vehicle-equivalent levels $\left(\right.$ Tx $\times$ time interaction: $F_{(2.4,23.7)}=9.5, p=0.001$; no effect on inactive lever pressing: $F_{(6,60)}=0.9, p=0.5$; Fig. $4 b$ ). Other reinstatement modalities were not reliably affected by $\mathrm{CNO}$ in $\mathrm{G}_{\mathrm{s}}$ rats (CNO-induced reinstatement: $F_{(2,16)}=0.6, p=0.56$; prime: $F_{(2,18)}=1.0, p=0.38$; YOH: $\left.F_{(2,8)}=1.6, p=0.26\right)$.

Modality-specific effects of $G_{i}$-mediated DA neuron inhibition on reinstatement

Effects of engaging $\mathrm{G}_{\mathrm{i}}$-coupled DREADDs in VTA DA neurons on reinstatement behavior was notably dependent on the type of reinstatement tested, presumably because DA neurons are differentially recruited during cocaine seeking under these different behavioral circumstances (Fig. $3 c$ ). In $\mathrm{G}_{\mathrm{i}}$ DREADD rats, CNO attenuated reinstatement elicited by either a cocaine-priming injection $\left(F_{(2,14)}=6.6, p=0.009\right)$ or YOH injection $\left(F_{(2,14)}=3.87\right.$, $p=0.046)$. Pressing on both levers was decreased during primed reinstatement (no interaction of Tx $\times$ lever: $F_{(2,14)}=0.96, p=$ $0.4)$, but only on the active lever during $\mathrm{YOH}$ reinstatement $\left(F_{(2,14)}=4.5, p=0.031\right)$. In the CNO-induced reinstatement test without cues, cocaine, or $\mathrm{YOH}, \mathrm{CNO}$ failed to affect the already low levels of lever pressing $\left(F_{(2,14)}=0.04, p=0.97\right)$. Intriguingly, despite the clear role for DA in conditioned seeking of cocaine and other rewards (Berridge, 2007; Everitt et al., 2008; Clark et al., 2012; Salamone and Correa, 2012; Mahler et al., 2014), CNO in $\mathrm{G}_{\mathrm{i}}$ rats did not significantly reduce cue-induced active lever pressing relative to vehicle day (no Tx effect on active lever pressing: $F_{(2,14)}=0.5, p=0.61$; Fig. $\left.3 c\right)$. Instead, CNO $(10 \mathrm{mg} / \mathrm{kg})$ in these animals increased pressing on the inactive lever $\left(F_{(2,18)}=3.7, p=\right.$ $0.045 ; 1 \mathrm{CNO}, p=0.7 ; 10 \mathrm{CNO}, p=0.048)$, despite the fact that presses on this lever were never reinforced at any point in training or testing [though we note that a dose $(0,1,10 \mathrm{mg} / \mathrm{kg}) \times$ lever (active, inactive) overall interaction was not statistically significant: $F_{(2,68)}=2.14, p=0.13$ ]. No similar effects of CNO were observed during other types of reinstatement in $G_{i}$ rats, or in other DREADD groups during reinstatement of any type $\left(F_{(2,14)}\right.$ values $<0.78$, $p$ values $>0.48$ ).

\section{Dual roles for DA neurons in economic demand for cocaine}

We next queried whether chemogenetic DA neuron modulation affects the free consumption of, or motivation for, cocaine. CNO in $\mathrm{G}_{\mathrm{q}}$ rats robustly decreased free cocaine consumption (Tx effect on $Q_{0} ; F_{(2,12)}=6.584, p=0.012$; Fig. $\left.5 a\right)$, indicating that increased $\mathrm{G}_{\mathrm{q}}$ signaling in these neurons partially substitutes for the subjective effects of cocaine, since less cocaine is desired at low effort. Demand elasticity ( $\alpha$ parameter) in $\mathrm{G}_{\mathrm{q}}$ rats was also decreased by $\mathrm{CNO}$, indicating that DA neuron activation increased the effort expended to obtain cocaine as doses decreased during the session, consistent with increased motivation for drug ( Tx effect on $\alpha$ : $F_{(2,12)}=11.44, p=0.002$; Fig. $5 b$ ). In contrast, the stimulation of $G_{s}$ DREADDs in DA neurons failed to significantly affect either free consumption or demand elasticity $\left(\alpha: F_{(2,14)}=\right.$ $\left.0.03217, p=0.97 ; Q_{0}: F_{(2,14)}=0.83, p=0.46\right)$. Stimulation of $\mathrm{G}_{\mathrm{i}}$ DREADDs in these neurons caused animals to consume more 


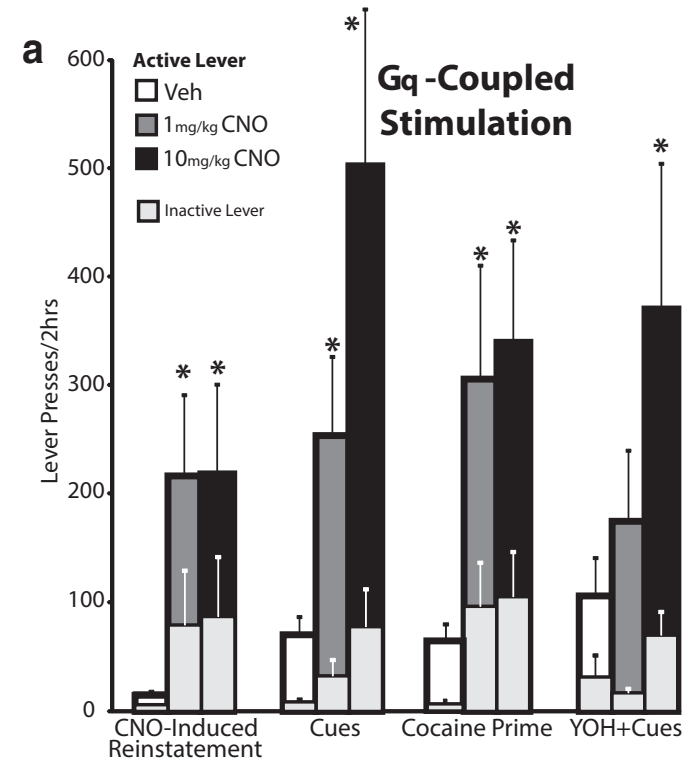

d

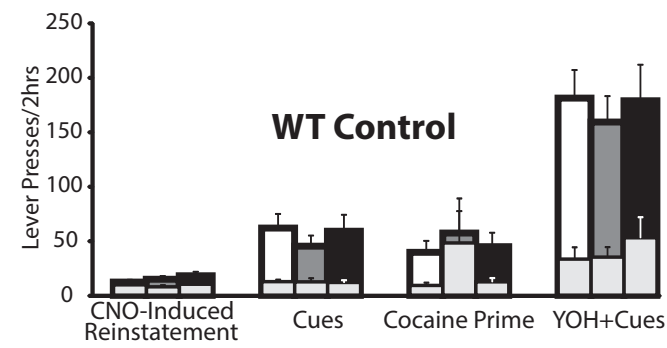

b

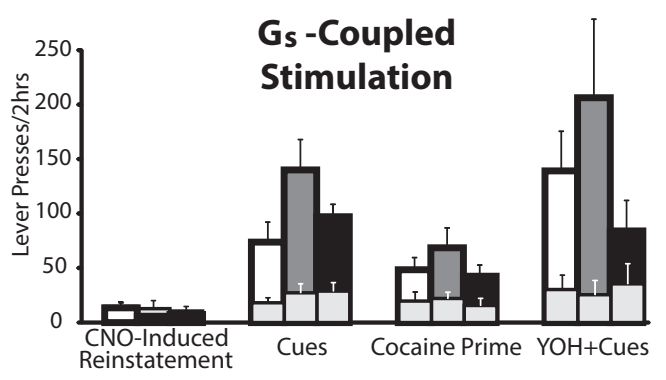

C

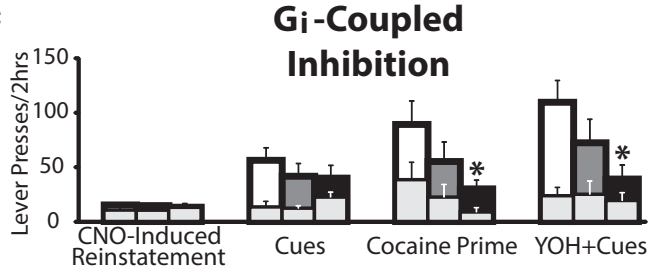

e

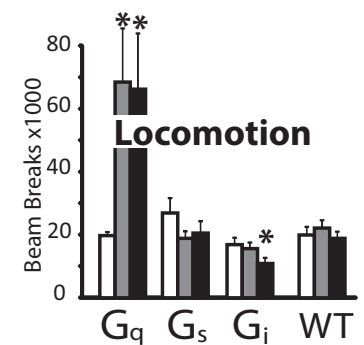

f

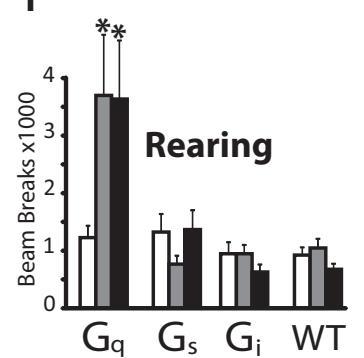

Figure 3. Reinstatement of cocaine seeking is modulated by chemogenetic DA neuron manipulations. $\boldsymbol{a}$, In $\mathrm{G}_{\mathrm{q}}$-DREADD rats, CN0 ( $1 \mathrm{mg} / \mathrm{kg}$, gray bars; $10 \mathrm{mg} / \mathrm{kg}$, black bars) increased cocaine seeking (relative to vehicle, white bars) in the absence ( $\mathrm{CNO}$-induced reinstatement) or the presence of cues, and after a cocaine prime (no cues) or yohimbine (YOH + cues) test $(10 \mathrm{mg} / \mathrm{kg}) . \boldsymbol{b}, \mathrm{CNO}$ failed to increase reinstatement in $\mathrm{G}_{\mathrm{s}}$-DREADD rats. $\boldsymbol{c}$, In $\mathrm{G}_{\mathrm{i}}$-DREADD rats, CNO reduced the priming effects of cocaine and the potentiation of cued responding by Y0H $(10 \mathrm{mg} / \mathrm{kg})$. $\boldsymbol{d}$, No effects of CN0 were observed in WT rats with no DREADD expression. Light gray bars indicate inactive lever presses for each test. ${ }^{*} p<0.05 \boldsymbol{e}, \boldsymbol{f}$, Effects of CN0 $(0,1$, $10 \mathrm{mg} / \mathrm{kg}$ ) on horizontal locomotion $(\boldsymbol{e})$ and rearing behavior is shown for DREADD-expressing and WT animals $(\boldsymbol{f})$. $\mathrm{G}_{q}$ stimulation increased and $\mathrm{G}_{i}$ stimulation decreased locomotor activity in a familiar environment. Individual rat data are shown in Figure 3-1, available at https://doi.org/10.1523/JNEUROSCI.0537-18.2018.f3-1, and locomotion time course is shown in Figure 3-2, available at https://doi.org/10.1523/JNEUROSCI.0537-18.2018.f3-2.

cocaine under low-effort conditions (Tx effect on $\mathrm{Q}_{0}: F_{(2,24)}=$ $3.771, p=0.038$ ), and demand became more elastic ( $\alpha$ increased, motivation decreased; Tx effect on $\left.\alpha: F_{(2,24)}=4.42, p=0.023\right)$, the opposite of $\mathrm{G}_{\mathrm{q}}$ stimulation effects. No effects of $\mathrm{CNO}$ were observed in WT control rats $\left(\alpha: F_{(2,14)}=1.765, p=0.207 ; Q_{0}\right.$ : $F_{(2,14)}=0.009, p=0.991$; for individual rat data: Fig. $5-1$, available at https://doi.org/10.1523/JNEUROSCI.0537-18.2018.f5-1), and $\mathrm{CNO}$ did not significantly alter inactive lever pressing during economic tests in any group $\left(\mathrm{G}_{\mathrm{q}}: F_{(2,12)}=1.096, p=0.365 ; \mathrm{G}_{\mathrm{s}}\right.$ : $F_{(2,12)}=0.147, p=0.86 ; \mathrm{G}_{\mathrm{i}}: F_{(1.36,17.64)}=3.22, p=0.08$; WT: $F_{(2,14)}=0.93, p=0.91$; Fig. $\left.5 c\right)$. These results together indicate that DA neurons play at least two distinct roles in cocaine intake, mediating the subjective effects of cocaine under low-effort conditions and facilitating the motivation to pursue cocaine under high-effort conditions. Future studies should determine whether the same DA neurons and projections underlie functions related to cocaine free consumption and motivation, or whether these are instead mediated by separate DA neurons within VTA.

Specificity and reversibility of DREADD manipulations Though CNO can have off-target effects affecting behavior (MacLaren et al., 2016; Gomez et al., 2017; Manvich et al., 2018), effects here were specific to DREADD-expressing rats, as there was no effect of either $\mathrm{CNO}$ dose in WT rats on: lever pressing during the CNO-induced reinstatement test $\left(F_{(2,18)}=1.13, p=\right.$ $0.344)$, cue $\left(F_{(2,18)}=0.73, p=0.495\right)$, primed $\left(F_{(2,18)}=1.42, p=\right.$ $0.27)$ or YOH reinstatement $\left(F_{(2,16)}=0.65, p=0.537\right.$; Fig. $\left.3 d\right)$, or cocaine demand $\left(\alpha: F_{(2,14)}=1.765, p=0.207 ; Q_{0}: F_{(2,14)}=0.009\right.$, $p=0.991$; Fig. 5). Neither did we find evidence of constitutive effects of DREADDs in the absence of CNO, as the behavior of $\mathrm{G}_{\mathrm{q}}$, $\mathrm{G}_{\mathrm{s}}$, and $\mathrm{G}_{\mathrm{i}} \mathrm{DREADD}$, and WT rats did not differ before $\mathrm{CNO}$ on cocaine self-administration (total self-administered cocaine infusions: $F_{(3,32)}$ values $<1.8$, $p$ values $>0.17$; Fig. $\left.6 a, b\right)$ or lever pressing during extinction (no day $\times$ group interaction: $F_{(8.7,92.8)}=1.6$, $p=0.14$; Fig. $6 c$ ), nor did groups differ on vehicle day in reinstatement behavior $\left(\mathrm{CNO}\right.$-induced reinstatement, $F_{(3,30)}=$ 0.189 ; cue, $F_{(3,32)}=0.27$; prime, $F_{(3,31)}=2.238 ; \mathrm{YOH}, F_{(3,25)}=$ 1.697; Fig. $6 d)$, cocaine demand $\left(\alpha: F_{(3,28)}=1.055, p=0.3839\right)$, or locomotor activity [horizontal activity (Horiz) $F_{(3,29)}=1.728$; vertical rearing behavior: $\left.F_{(3,29)}=0.664\right]$.

Given the intimate involvement of G-protein signaling in synaptic plasticity and prior reports of the persistent effects of $G_{s}$ DREADD stimulation (Ferguson et al., 2013; Nakajima et al., 2016), we searched for persistent effects of prior-day CNO (compared with those of prior-day Veh) on behavior. No such effects were found during extinction retraining days following each 

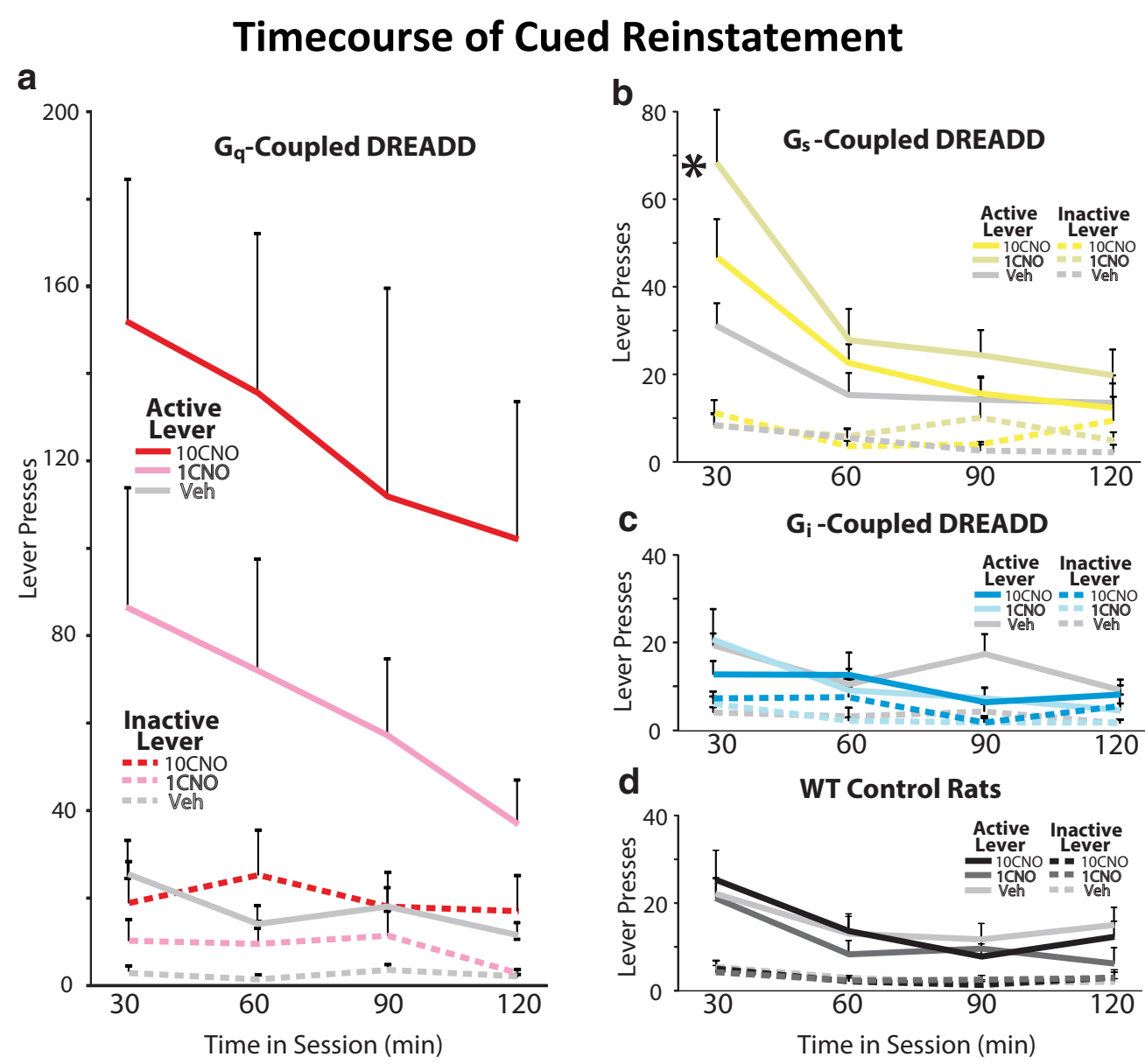

Figure 4. Time course of cue-induced reinstatement. $\boldsymbol{a}-\boldsymbol{d}$, Time course of active lever (solid lines) and inactive lever (dashed lines) are shown for $\mathrm{G}_{\mathrm{q}}(\boldsymbol{a}), \mathrm{G}_{\mathrm{s}}(\boldsymbol{b})$, $\mathrm{G}_{\mathrm{i}} \mathrm{DREADD}(\boldsymbol{c})$, and WT control $(\boldsymbol{d})$ rats after vehicle or CNO administration $(1,10 \mathrm{mg} / \mathrm{kg}$ ). Data are shown in $30 \mathrm{~min}$ bins throughout the $120 \mathrm{~min}$ session. Lines represent the mean, and error bars represent the SEM. * $p<0.05$, interaction of dose $\times$ time.

$\mathrm{CNO} /$ vehicle reinstatement test (extinction test: $F_{(2,16)}=0.141$; cue: $F_{(2,20)}=0.331$; prime: $F_{(2,18)}=0.57$ YOH: $\left.F_{(2,50)}=0.078\right)$, or on cocaine intake following $\mathrm{CNO} /$ vehicle economic demand tests (no effect of Tx on $\alpha$ : $F_{(2,36)}=1.229$; or no effect of $\mathrm{Q}_{0}$ on $\alpha$ : $F_{(2,36)}=0.846$; Fig. $\left.7 e, f\right)$, though subtler carryover effects cannot be totally excluded, as nonsignificant trends to this effect were occasionally seen (Fig. $7 a, f$ ). Together, these findings show that DREADD manipulations specifically and reversibly increase or decrease VTA DA neuron function, as expected.

To characterize potential nonspecific motor effects of VTA DA neuron manipulations that could alter lever pressing, in a subset of each DREADD group, we examined the effects of systemic CNO on Horiz and rearing in a prehabituated test cage. CNO increased activity in $\mathrm{G}_{\mathrm{q}}$ rats across the entire $2 \mathrm{~h}$ session (Horiz: $F_{(1.042,5.21)}=6.774, p=0.046$; Rears: $F_{(2,10)}=6.038, p=$ 0.019 ), trended toward decreasing activity in $G_{i}$ rats (Horiz: $F_{(2,16)}=3.253, p=0.065$; Rears: $\left.F_{(2,16)}=2.239, p=0.139\right)$, and did not affect activity in $\mathrm{G}_{\mathrm{s}}$ or WT rats $\left(\mathrm{G}_{\mathrm{s}}\right.$ Horiz: $F_{(2,20)}=1.43$, $p=0.263$; Rears: $F_{(2,20)}=2.007, p=0.161$; WT Horiz: $F_{(2,12)}=$ $1.364, p=0.293$; Rears: $F_{(2,12)}=3.129, p=0.081$; Fig. $\left.3 e, f\right)$. CNO locomotor stimulation persisted for at least $2 \mathrm{~h}$ in $\mathrm{G}_{\mathrm{q}}$ rats (no interaction of Tx $\times$ time: $F_{(6,36)}=1.184, p=0.337$; Fig. 3-2, available at https://doi.org/10.1523/JNEUROSCI.0537-18.2018. f3-2). Reinstatement effects of $\mathrm{G}_{\mathrm{q}}$ stimulation were stronger than locomotor activation effects in the same rats (mean cue reinstatement effect of $10 \mathrm{CNO}, 1116.4 \%$ of vehicle day; Horiz locomo- tion effect, 361.5\%), and the locomotion effects versus the motivation-enhancing effects of $\mathrm{CNO}$ in the same $\mathrm{G}_{\mathrm{q}}$ rats were not correlated (change from vehicle Horiz not related to $\mathrm{CNO}$ effect on: cue reinstatement, $r=-0.794, p=0.06$; CNO-induced reinstatement, $r=-0.494, p=0.32$; prime: $r=-0.539, p=$ 0.27; YOH, $r=-0.072, p=0.892$ ).

\section{Pathway-specific DREADD experiments}

Validation of presynaptic DA release in NAc

DREADDs are robustly anterogradely transported and are readily observed in axons in forebrain DA neuron targets, including NAc, mPFC, and BLA. To verify chemogenetic modulation of presynaptic DA release, we prepared coronal slices of NAc from TH:Cre rats with $G_{q}, G_{s}$, or $G_{i}$ DREADD-expressing VTA DA neurons, and DA release was measured using fast-scan cyclic voltammetry (Ferris et al., 2013; Brodnik and España, 2015; Bucher and Wightman, 2015) before and after washing CNO (5 $\mu \mathrm{M})$ onto the slice, and in response to a single electrical pulse or multiple pulses across tonic and phasic frequencies (five pulses at $5-40 \mathrm{~Hz})$. CNO increased evoked DA in $\mathrm{G}_{\mathrm{q}}$ rats $\left(F_{(1,21)}=5.472\right.$, $p=0.029)$ and decreased it in $\mathrm{G}_{\mathrm{i}}$ rats $\left(F_{(1,21)}=12.77, p=\right.$ $0.0018)$, but did not affect the release in $\mathrm{G}_{\mathrm{s}}$ or WT rats $\left(F_{(1,21)}=\right.$ $0.153, p=0.6989$; Fig. $8 a$ ). This indicates that DREADDs can be used to bidirectionally modulate DA release from VTA DA neuron terminals in a pathway-specific manner. 

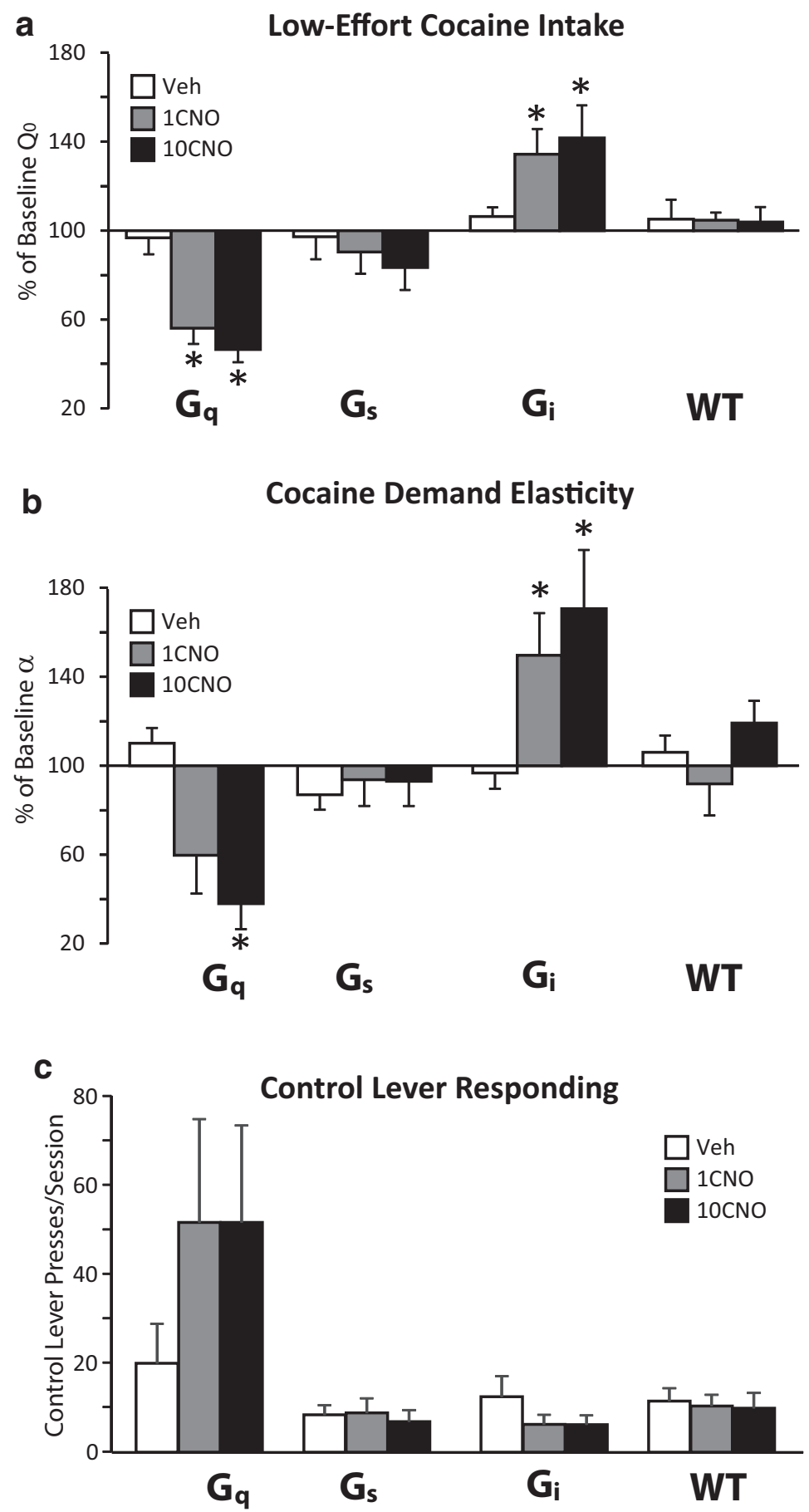

Figure 5. DA neuron modulation affects low-effort cocaine intake and demand elasticity. $\boldsymbol{a}$, Effects of $\mathrm{CNO}(0,1$, or $10 \mathrm{mg} / \mathrm{kg})$ in $G_{q^{\prime}} G_{s^{\prime}}$ and $G_{i}$ DREADD rats, or WT rats on free cocaine intake $\left(Q_{0}\right)$ are depicted. $\boldsymbol{b}$, Effects of $C N O$ on demand elasticity $(\alpha)$ are depicted. When VTA DA neurons were stimulated, rats preferred less cocaine but worked harder to obtain this lower dose. When DA neurons were inhibited, subjects preferred more cocaine but were less willing to work hard to obtain it. c, No effects of CNO were found on control (inactive) lever responding during economic demand tests. ${ }^{*} p<0.05$. Individual rat data are shown in Figure 5-1, available at https://doi.org/10.1523/JNEUROSCI.0537-18.2018.f5-1

\section{Efferent target specificity of $G_{q} D R E A D D$ stimulation effects on reinstatement}

Given the robust enhancement of reinstatement by $G_{q}$ DA neuron stimulation, we next sought to determine the corresponding contributions of VTA DA neuron projections to mPFC, NAc, and BLA for reinstatement or food intake behaviors. We and others have shown that applying CNO directly into the terminal fields of $\mathrm{G}_{\mathrm{i}}$ DREADD-expressing neurons inhibits axonal release of neu- rotransmitters (Mahler et al., 2014; Stachniak et al., 2014; Wang et al., 2015; MacLaren et al., 2016; Lichtenberg et al., 2017), and here we examined for the first time whether projection-specific stimulation of dorsal mPFC, NAcCore, or BLA VTA DA neuron efferents affects behavior. A separate group of TH:Cre rats with $\mathrm{G}_{\mathrm{q}}$ DREADDs in VTA and chronic bilateral cannulae in NAc, mPFC, or BLA were trained to self-administer cocaine, then extinguished. Effects of CNO microinjections (vs vehicle) on cocaine seeking in the absence or presence of response-contingent cues (CNO-induced or cued reinstatement tests) were measured. CNO injections in any of the three structures increased active lever pressing during cued reinstatement, indicating a similarly increased impact of cues after stimulation of each DA neuron projection $\left(\mathrm{mPFC}: F_{(1,8)}=14.024, p=\right.$ 0.006; NAc: $F_{(1,12)}=5.429, p=0.038$; BLA: $F_{(1,8)}=6.424, p=0.035$; Fig. $8 f-h$ and Fig. $8-1 a$, available at https://doi.org/10.1523/ JNEUROSCI.0537-18.2018.f8-1). Increased pressing was specific to the active lever for $\mathrm{mPFC}$ and BLA, but not significantly for NAc $\left(\mathrm{Tx} \times\right.$ lever interaction: $\mathrm{mPFC}, F_{(1,8)}=$ 8.676, $p=0.019$; NAc, $F_{(1,12)}=3.887, p=$ 0.072 ; BLA, $\left.F_{(1,8)}=8.26, p=0.021\right)$. Importantly, NAc CNO, but not mPFC or BLA $\mathrm{CNO}$, also induced cocaine seeking in the absence of cues, cocaine, or YOH (Tx effect on active lever pressing in $\mathrm{CNO}$-induced reinstatement: $\mathrm{mPFC}, F_{(1,7)}=0.104, p=$ 0.757; NAc, $F_{(1,12)}=15.448, p=0.002$; BLA, $F_{(1,8)}=0.019, p=0.894$; Fig. $8 f-h$ and Fig. 8-1b, available at https://doi.org/ 10.1523/JNEUROSCI.0537-18.2018.f8-1). These data show that the stimulation of VTA DA neuron terminals in NAc alone, but not $\mathrm{mPFC}$ or BLA alone, is sufficient to generate seeking behavior even in the absence of endogenous circuit activity induced by Pavlovian cues. In contrast, microinjection of the same CNO dose in NAc of WT rats (lacking DREADD expression) failed to induce reinstatement $\left(t_{(6)}=0.23, p=0.83\right)$ or alter cue reinstatement $\left(t_{(6)}=-0.90, p=\right.$ 0.40 ), demonstrating that $1 \mathrm{mM} \mathrm{CNO}$ in NAc did not display off-target effects in the absence of DREADDs (Fig. $8 a$ and Fig. 8-1b, available at https://doi.org/10.1523/ JNEUROSCI.0537-18.2018.f8-1). No effects of intracerebroventricular $\mathrm{CNO}$ on active/inactive lever ratio were seen in any brain region (no drug $\times$ region interaction on the ratio of active to inactive lever pressing: $\left.F_{(2,28)}=2.02, p=0.15\right)$.

Pathway-specific DA-BLA stimulation of unconditioned reward In the same rats, we next examined a simple unconditioned reward procurement behavior (spontaneous chow intake) that is often linked to the activation of incentive motivation-linked 


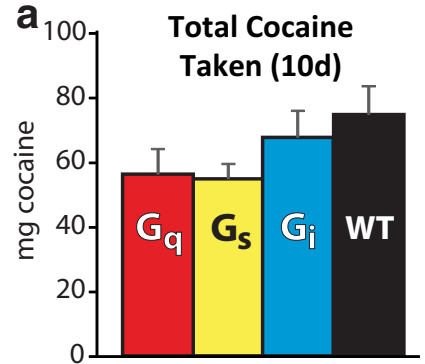

C

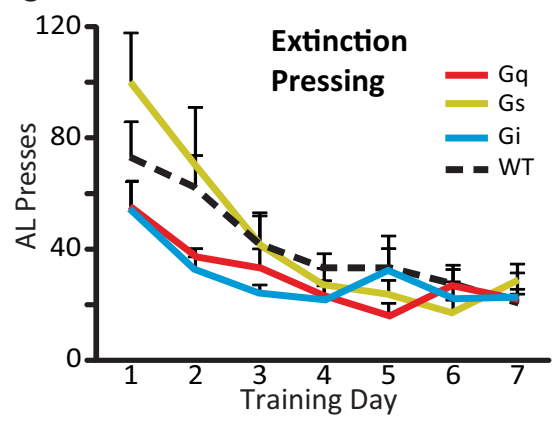

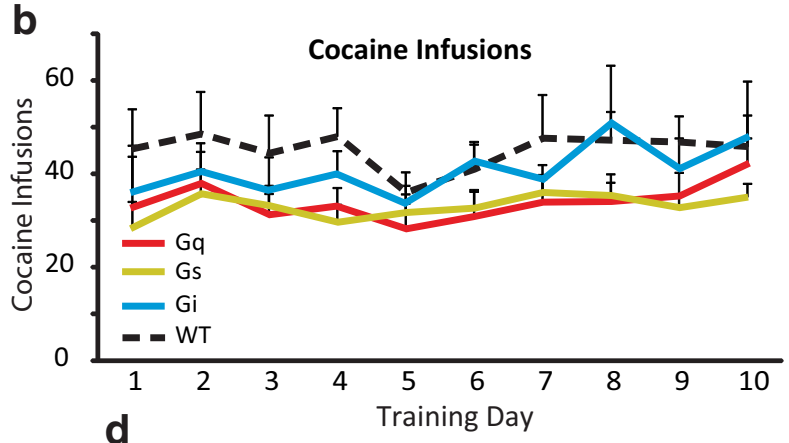

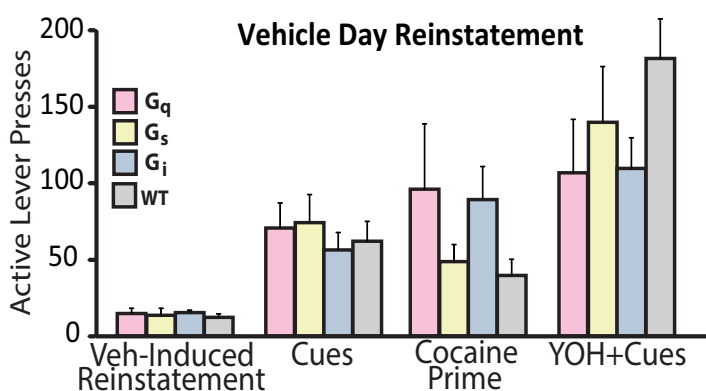

Figure 6. DREADDs do not affect behavior in the absence of CNO. No significant effects of DREADD expression are observed in the absence of CN0. $\boldsymbol{a}-\boldsymbol{d}$, Rats with DREADDs $\left(G_{q^{\prime}}\right.$, red; $G_{s^{\prime}}$ yellow; $\mathrm{G}_{\mathrm{i}}$, blue) or no DREADDs (WT controls, black) did not differ in the total number of milligrams of cocaine self-administered throughout training ( $\boldsymbol{a}$ ), the number of daily cocaine infusions across the $10 \mathrm{~d}$ training period $(\boldsymbol{b})$, active lever pressing across the first $7 \mathrm{~d}$ of extinction training $(\boldsymbol{c})$, or active lever pressing on reinstatement $(\boldsymbol{d})$. Bars and lines represent the mean, and error bars represent the SEM.

a

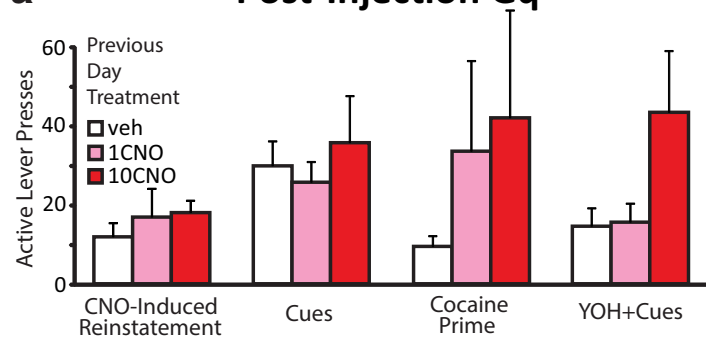

C

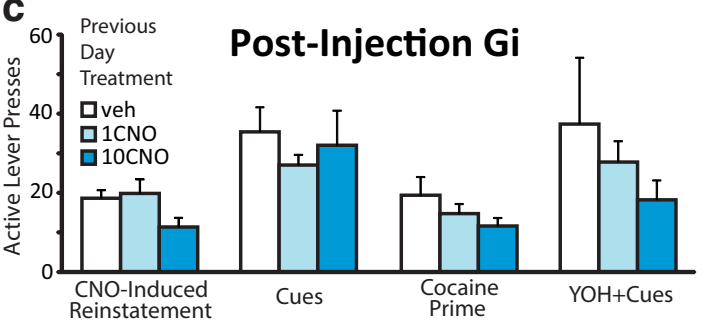

e

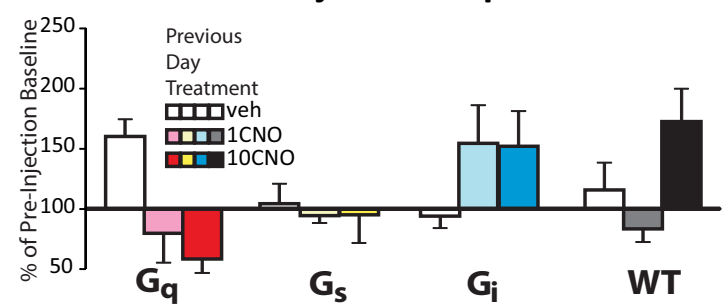

b

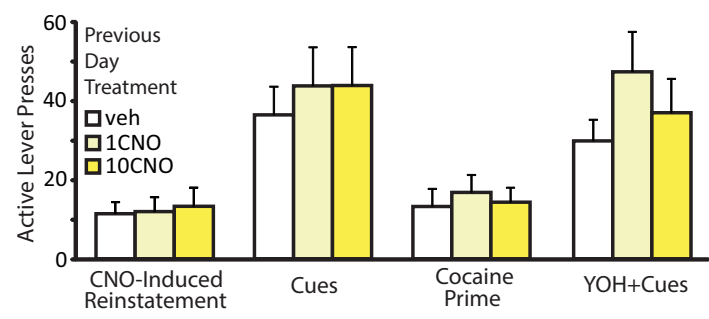

d

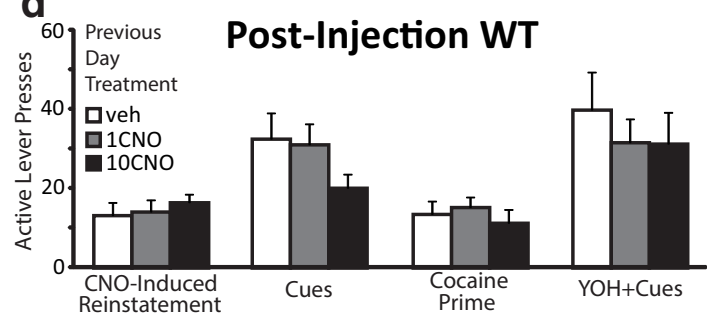

f

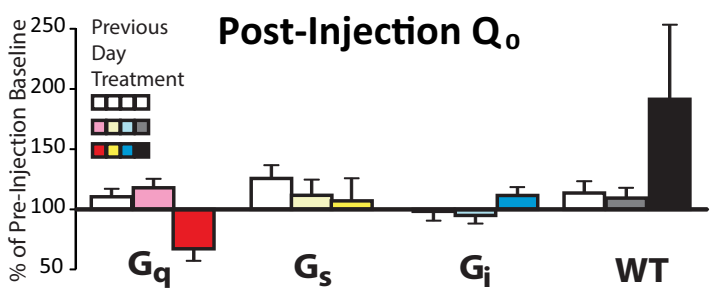

Figure 7. CNO does not have persistent effects on behavior. $\boldsymbol{a}-\boldsymbol{d}$, No evidence for long-lasting effects of CNO in $G_{q}-D R E A D D ~(a), G_{s}-D R E A D D(b), G_{i}-D R E A D D(c)$, or WT control (d) rats were found, as demonstrated with active lever presses on the extinction retraining trial held $24 \mathrm{~h}$ after the injection of vehicle (white bars), $1 \mathrm{mg} / \mathrm{kg}$ CNO (light red, yellow, blue, black bars), or $10 \mathrm{mg} / \mathrm{kg}$ CNO (dark color bars). $\boldsymbol{e}, \boldsymbol{f}$, Similarly, no persistent effects of prior-day CNO were observed on demand elasticity $(\alpha ; \boldsymbol{e})$ or free cocaine intake $\left(Q_{0} ; \boldsymbol{f}\right)$. Bars represent the percentage of preinjection baseline on day following administration of vehicle, or 1 or $10 \mathrm{mg} / \mathrm{kg}$ CNO. 

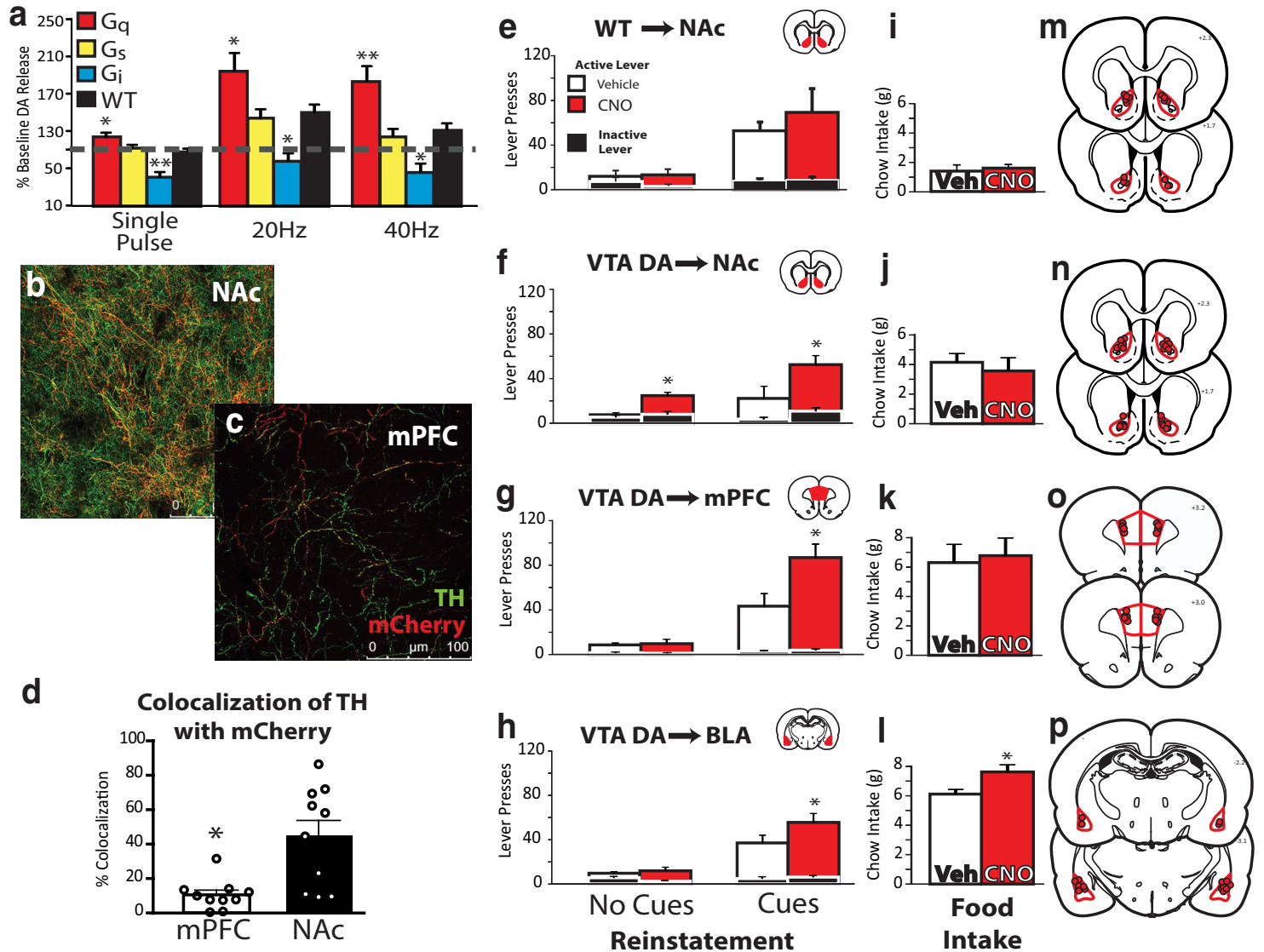

Figure 8. Chemogenetic pathway-specific stimulation of VTA DA terminals. $\boldsymbol{a}$, In acute coronal NAc slices from rats with $G_{q}$ DREADDs in VTA DA neurons, DA release was evoked with local electrical stimulation (single pulse, 20 or $40 \mathrm{~Hz}$ ) before or after bath application of CNO $(1 \mu \mathrm{m})$, measured using cyclic voltammetry. Bars depict the percentage of baseline (pre-CNO) DA release after CNO administration in $\mathrm{G}_{q^{-}}, \mathrm{G}_{s^{-}}$, or $\mathrm{G}_{\mathrm{i}}$ - DREADD rats, or WT rats. CNO facilitated DA release in $\mathrm{G}_{\mathrm{q}}$-DREADD rats at all stimulation parameters and decreased DA release in $\mathrm{G}_{\mathrm{i}}-\mathrm{DREADD}$ rats. No effects of $\mathrm{CN} 0$ were seen in $\mathrm{G}_{s}-\mathrm{DREADD}$ or WT rats. $\boldsymbol{b}, \boldsymbol{c}, \mathrm{G}_{q}$ DREADDs are robustly transported to targets including NAc $(\boldsymbol{b})$ and $\mathrm{mPFC}(\boldsymbol{c})$. $\boldsymbol{d}$, axon terminals of VTA TH( + ) neurons, labeled with mCherry (red) colocalized with tyrosine hydroxylase (TH; green) to a greater extent in NAc compared with mPFC. e-I, Effects of CNO microinjection into NAc of WT rats without DREADDs $(\boldsymbol{e}, \boldsymbol{i}), \mathrm{NAC}_{\text {of }} \mathrm{G}_{\mathrm{q}} \mathrm{DREADD}$ rats $(\boldsymbol{f}, \boldsymbol{j}), \mathrm{mPFC}$ of $\mathrm{G}_{\mathrm{q}}$ rats $(\boldsymbol{g}, \boldsymbol{k})$, or BLA of $\mathrm{G}_{\mathrm{q}}$ rats $(\boldsymbol{h}, \boldsymbol{I})$ on reinstatement with (right bars) or without cues (left bars; $\left.\boldsymbol{e}-\boldsymbol{h}\right)$, or on $2 \mathrm{~h}$ chow intake in a separate test with the same rats $(\boldsymbol{i}-\boldsymbol{I}) .{ }^{*} p<0.05,{ }^{* *} p<0.01 . \boldsymbol{m}-\boldsymbol{p}$, Microinjection sites are shown for WT $(\boldsymbol{m}), \mathrm{NAcG}_{\mathrm{q}}(\boldsymbol{n}), \mathrm{mPFC}_{\mathrm{q}}(\boldsymbol{o})$, and BLA G$(\boldsymbol{p})$ animals. Individual rat data are shown in Figure 8-1, available at https://doi.org/10.1523/JNEUROSCI.0537-18.2018.f8-1.

mesolimbic pathways (Berridge and Robinson, 1998; Baldo and Kelley, 2007; Mahler and Berridge, 2009, 2012). Food intake was measured for $2 \mathrm{~h}$ after intra-mPFC, NAc, or BLA Veh/CNO microinjections (the fifth and sixth microinjections these rats received after reinstatement tests; Mahler and Berridge, 2012; Mahler et al., 2013, 2014; Fig. 8i-l and Fig. 8-1c, available at https://doi.org/10.1523/JNEUROSCI.0537-18.2018.f8-1). Neither $\mathrm{mPFC}$ nor NAc CNO injections altered spontaneous eating (mPFC: $t_{(9)}=0.312, p=0.762$; NAc: $t_{(10)}=0.782, p=0.452$ ), but BLA CNO increased food intake $\left(t_{(6)}=2.466, p=0.049\right)$ - to our knowledge, the first demonstration of unconditioned feeding induced by a manipulation of BLA. No effects of intra-NAc CNO was seen in WT rats $\left(t_{(6)}=0.35, p=0.74\right.$; Fig. $8 e$ and Fig. $8-1$, available at https://doi.org/10.1523/JNEUROSCI.0537-18.2018. f8-1). These findings show novel roles for DA neuron efferents to NAc in cocaine seeking, and to BLA in unconditioned food intake.

\section{Colocalization of axonal DREADDs with TH}

Though DA neuron axonal stimulation had behavioral effects consistent with the enhancement of DA release, and such enhanced DA release is observed in NAc (Fig. $8 a$ ), DA neurons release other transmitters in addition to DA, including glutamate (Sulzer et al., 1998; Lapish et al., 2006; Hnasko et al., 2012;
Trudeau et al., 2014; Zhang et al., 2015; Barker et al., 2016) and GABA (Tritsch et al., 2012; Stamatakis et al., 2013; Root et al., 2014). Perhaps relatedly, a marked lack of colocalization of mCherry [expressed exclusively in $\mathrm{TH}(+)$ neurons in VTA; Mahler et al., 2014] and TH (a requisite enzyme for DA production; Zhang et al., 2015) was observed in some targets, especially in $\mathrm{mPFC}$ (Fig. 8c). There was a significantly higher percentage of DREADD signal (red) colocalized with TH terminals (green) in NAc (Fig. $8 b)$ when compared with the $\operatorname{mPFC}\left(t_{(18)}=3.530 ; p=\right.$ 0.0024; Fig. $8 d$ ). Further inquiry into the neurochemical identity and behavioral functions of these $\mathrm{TH}$-negative terminals originating from $\mathrm{mPFC}$-projecting DA neurons is warranted, particularly given recent reports of marked neurochemical heterogeneity within VTA DA neurons and their axons (Tritsch et al., 2012; Trudeau et al., 2014; Zhang et al., 2015; Barker et al., 2016).

\section{Discussion}

Here we systematically compared the effects of chemogenetically manipulating VTA DA neurons, or their individual forebrain projections, during cocaine-taking and cocaine-seeking behaviors. These experiments revealed powerful, fundamentally modulatory roles for DA neurons in reinforcement, incentive motivation, and 
decision-making. Behavioral effects depended upon the GPCR signaling system and anatomical pathway which was experimentally engaged, as well as the behavioral and pharmacological context the animals were in. Overall, results show that the role of DA neurons in cocaine seeking is ultimately achieved by modulating behaviorally relevant mesocorticolimbic circuits.

\section{VTA DA neuron $\mathrm{G}_{\mathrm{q}}$-stimulated cocaine relapse}

We find several distinct roles for VTA DA neurons in reinstatement behavior. $G_{\mathrm{q}}$ DREADD stimulation reinstated extinguished cocaine seeking in the absence of cocaine cues, priming injections, or pharmacological stress-indicating the sufficiency of DA neuron $G_{q}$ signaling for cocaine seeking. $G_{q}$ augmentation of reinstatement behavior was strongest in the presence of response-contingent cocaine cues, suggesting a synergistic relationship between DA neuron stimulation and cue-induced cocaine seeking. Though DA neuron stimulation also increased general locomotor activity and inactive lever pressing during some types of reinstatement (by up to $350 \%$ of vehicle day), the magnitude of these effects was still weaker than that for the stimulation of cocaine seeking, and was uncorrelated with motivation-enhancing effects in individual rats. Furthermore, the suppression of low-effort responding $\left(Q_{0}\right)$ by $G_{q}$ stimulation argues against mere locomotor activation explaining the results, but instead argues for the recruitment of both general arousal and reinforcement/motivation functions of VTA DA neurons in these studies. However, it is notable that motor activation typically accompanies increased motivation; these processes are intertwined, and DA neurons play a role in both of them.

Stimulating $\mathrm{G}_{\mathrm{s}}$ DREADDs in VTA DA neurons had only modest effects on cocaine-seeking and other behaviors. Indeed, the only significant effect of $G_{s}$ stimulation was a mild increase in cue-induced cocaine seeking. In contrast, $\mathrm{G}_{\mathrm{q}}$ stimulation in animals with equivalent DREADD expression dramatically increased cued cocaine seeking. As CNO enhanced DA neuron activity in $G_{s}$ rats (as measured by Fos and in vitro firing), and $G_{s}$ DREADDs have robust behavioral effects in other experiments (Ferguson et al., 2011, 2013; Gourley et al., 2016), our findings are unlikely to result simply from insufficient activity of the $G_{s}$ DREADD receptor. Instead, these findings reveal qualitatively different behavioral effects of $G_{q}$ versus $G_{s}$ signaling in VTA DA neurons, with preferential activation of motivation by $\mathrm{G}_{\mathrm{q}}$ stimulation. Although not assessed here, $G_{q}$ and $G_{s}$ activation could differentially modulate the firing patterns of DA cells or the amount of DA released by them, as occurs with endogenous GPCR signaling in VTA neurons (Fiorillo and Williams, 2000; Foster et al., 2014). Also, given the crucial roles for cAMPdependent $G_{s}$ signaling in DA neuron plasticity (Shen et al., 2013), and the previous reports of $G_{s}$ DREADD stimulation causing persistent behavioral effects (Ferguson et al., 2013; Nakajima et al., 2016), it is also possible that $\mathrm{G}_{\mathrm{s}}$ signaling plays a larger role in learning than in the expression of previously learned motivation; this possibility should be tested in future studies.

\section{Chemogenetic inhibition reveals behavior-specific roles for VTA DA neurons}

Inhibiting DA neuron activity with $G_{i}$ DREADDs decreased some, but not all, types of reinstatement behavior. Engaging $G_{i}$ DREADDs reduced the reinstatement elicited by either a cocaine prime or by cues plus the pharmacological stressor yohimbine. Given the known modulation of conditioned reward seeking by VTA DA neurons, and the fact that contralaterally disconnecting
VTA DA neurons from direct connectivity with ventral pallidum (VP) using $G_{i}$ DREADDs blocks cue-induced cocaine reinstatement (Mahler et al., 2014), it is surprising that bilateral inhibition of VTA DA neurons via $G_{i}$ DREADDs failed to block cue-induced reinstatement. Instead, this manipulation appeared to alter the targeting of cue-triggered seeking, increasing the pressing of an inactive control lever that never yielded cocaine or cues without affecting cocaine lever pressing or control lever pressing during economic demand tests. Intriguingly, increased responding on an inactive manipulandum for cocaine was also previously reported for systemic DA antagonist administration (Willuhn et al., 2012), potentially representing a shift to the exploration of alternative strategies for attaining cocaine, rather than mere reinstatement inhibition, as occurs with VP/VTA DA neuron disconnection. Perhaps the opposing behavioral roles for VP GABA and glutamate neurons, or their distinct connectivity with VTA neuronal subpopulations (Faget et al., 2018; Tooley et al., 2018), contributes to this pattern of effects. Moreover, a role for VTA DA projections to VP (Heidenreich et al., 1995; Smith and Berridge, 2007; Stout et al., 2016; Chang et al., 2018), also disrupted in our prior study (Mahler et al., 2014), cannot be excluded. Regardless, our present findings with "global” VTA DA neuron DREADD inhibition points to a previously unappreciated complexity in DA neuron function in motivation and decisionmaking.

\section{Dual roles for DA neurons in high- and low-effort cocaine intake}

Prior studies suggest that DA mediates the reinforcing subjective effects of psychostimulants, so blocking DA receptors causes rats to self-administer more cocaine to compensate (Suto and Wise, 2011; Willuhn et al., 2012). However, DA blockade also decreases effortful drug seeking, implying a role in motivation (Berridge, 2007; Salamone and Correa, 2012). Here, we concurrently tested both of these putative roles for DA in a within-session cocaine behavioral economic paradigm, and show that DA neurons participate in both processes. At the start of each session, preferred cocaine levels are easily attained, and cocaine intake was increased when DA neurons were inhibited or decreased when DA neurons were stimulated. This is consistent with the subjective effects of cocaine involving DA released from VTA neurons. However, later in the session rats were required to work harder to defend preferred cocaine blood levels. Then, DREADD stimulation increased responding, whereas $G_{i}$ inhibition decreased it. This finding is consistent with the view that VTA DA neurons drive the motivation for cocaine. Plainly, when VTA DA neurons were stimulated, rats wanted less cocaine but worked harder to obtain what they wanted. During inhibition of DA neurons, rats wanted more cocaine but were less willing to work hard to obtain it. Therefore, these results indicate that VTA DA neurons are involved in both the subjective reinforcing, and motivational activating effects of cocaine, rather than playing any single role in reward.

\section{Functional heterogeneity of DA neuron efferents}

VTA DA neurons show remarkable molecular and physiological diversity, related both to the efferent targets of individual neurons and the behaviors these neurons regulate (Roeper, 2013; Lammel et al., 2014a; Barker et al., 2016; Saunders et al., 2018). Here we demonstrate that stimulating DA neuronal projections to NAc, mPFC, or BLA is sufficient for enhancing the motivational impact of previously learned cocaine cues, but only DA neuron terminals in NAc are sufficient to elicit reinstatement in 
the absence of discrete cues. We also found that stimulating DA neuron terminals in BLA enhances food intake, the first demonstration of BLA involvement in unconditioned feeding. We note, however, that chemogenetic stimulation of terminals of VTA $\mathrm{TH}(+)$ neurons via CNO microinjection also likely causes the release of both DA and non-DA transmitters (Tritsch et al., 2012; Trudeau et al., 2014; Barker et al., 2016) — especially in mPFC, where few DREADD-expressing axons extensively coexpressed $\mathrm{TH}$ in these cocaine-experienced rats. Notably, intracranial CNO $(1 \mathrm{~mm})$ effects are DREADD specific here (Fig. $8 e, i)$ and previously (Mahler et al., 2014; Ge et al., 2017; Lichtenberg et al., 2017; McGlinchey and Aston-Jones, 2018; Mahler and Aston-Jones, 2018), suggesting minimal nonspecific behavioral effects of CNO or its metabolites here. These results call for further study of the relative roles of DA neuron projections to forebrain subnuclei, especially NAc core versus shell, and dorsal versus ventral mPFC, which would be expected to play distinct roles in cue-triggered reward seeking (Corbit et al., 2001; Di Chiara, 2002; Floresco et al., 2008; Hamlin et al., 2008; Peters et al., 2008; Ostlund et al., 2011; Saddoris et al., 2013; Moorman et al., 2015; Gourley and Taylor, 2016). No studies have shown that, like analogous optogenetic approaches, $\mathrm{CNO}$ microinjection upon $\mathrm{G}_{\mathrm{q}}$-DREADDexpressing axons causes antidromic excitation of DA neurons; however, we cannot exclude this possibility. Further work should also determine the pathway-specific necessity of DA neurons for reinstatement (e.g., using with $G_{i}$ inhibitory DREADDs). Together, these data show for the first time that presynaptic $G_{q}$ stimulation of DA neuron axons via $\mathrm{CNO}$ microinjection affects behavior, and does so in a pathway-specific manner.

\section{Effects of DREADD manipulations on VTA DA neuron activity}

Our validation of bidirectional chemogenetic modulation of DA neurons in TH:Cre rats revealed several mechanisms through which the activation of DREADD receptors modifies DA system activity. CNO increased activity of $\mathrm{G}_{\mathrm{q}}$ DREADD-expressing DA neurons as measured by in vitro firing and Fos expression, and also recruited otherwise quiescent populations of DA neurons in anesthetized rats and indirectly reduced Fos in $\mathrm{TH}(-)$ VTA neurons. $\mathrm{CNO}$ also increased Fos and in vitro firing in $\mathrm{G}_{\mathrm{s}}$ rats, but did not affect Fos in $\mathrm{TH}(-)$ VTA neurons or alter population activity in vivo. Finally, $\mathrm{CNO}$ in $\mathrm{G}_{\mathrm{i}}$ rats failed to reduce firing or Fos in $\mathrm{DA}$ neurons under the measured circumstances, in which DA neuron firing was not robustly stimulated by endogenous behaviorrelated activity (in vitro slices, anesthetized rats, or home-cage conditions for Fos).

We also examined the ability of DREADDs to presynaptically modulate NAc DA release, as is possible with inhibitory DREADDs in other neural circuits (Mahler et al., 2014; Stachniak et al., 2014; Buchta et al., 2017; Ge et al., 2017; Lichtenberg et al., 2017; McGlinchey and Aston-Jones, 2018). Electrically evoked DA release was augmented by $\mathrm{CNO}$ in slices from $\mathrm{G}_{\mathrm{q}}$ rats, reduced in $G_{i}$ rats, and unaffected in rats without DREADDs or with $G_{s}$ DREADDs, thereby validating the efficacy of axonally applied CNO to bidirectionally modulate $\mathrm{DA}$ release via $\mathrm{G}_{\mathrm{i} / \mathrm{o}^{-}}$or $\mathrm{G}_{\mathrm{q}}$-coupled signaling.

\section{Translational implications of chemogenetic circuit interventions}

A key advantage of DREADDs for intervening in neural circuits is the potential for the translation of this or related approaches to the mental health clinic. The proximate cause of psychiatric disorders involves the abnormal function of neural circuits, and a chemogenetic approach could therefore be useful in correcting neural activity with potentially fewer side effects than traditional psychotropic drugs or chronically implanted hardware. Such approaches will require extensive preclinical evaluation, but initial primate studies indicate safety and efficacy of DREADDs for modulating behavior and circuit activity (Eldridge et al., 2016; Grayson et al., 2016; Nagai et al., 2016; Upright et al., 2018). Indeed, the largest limitation to pursing this approach in the clinic may be determining circuits that, if successfully modulated, would treat chronic psychiatric disorders in humans. The present results illustrate that even selective circuit manipulations like those of DA neurons here can have nuanced, context-specific effects on behavior.

\section{References}

Adamantidis AR, Tsai HC, Boutrel B, Zhang F, Stuber GD, Budygin EA, Touriño C, Bonci A, Deisseroth K, de Lecea L (2011) Optogenetic interrogation of dopaminergic modulation of the multiple phases of rewardseeking behavior. J Neurosci 31:10829-10835. CrossRef Medline

Baldo BA, Kelley AE (2007) Discrete neurochemical coding of distinguishable motivational processes: insights from nucleus accumbens control of feeding. Psychopharmacology 191:439-459. CrossRef Medline

Barker DJ, Root DH, Zhang S, Morales M (2016) Multiplexed neurochemical signaling by neurons of the ventral tegmental area. J Chem Neuroanat 73:33-42. CrossRef Medline

Bentzley BS, Fender KM, Aston-Jones G (2013) The behavioral economics of drug self-administration: a review and new analytical approach for within-session procedures. Psychopharmacology (Berl) 226:113-125. CrossRef Medline

Bentzley BS, Jhou TC, Aston-Jones G (2014) Economic demand predicts addiction-like behavior and therapeutic efficacy of oxytocin in the rat. Proc Natl Acad Sci U S A 111:11822-11827. CrossRef Medline

Berridge KC (2007) The debate over dopamine's role in reward: the case for incentive salience. Psychopharmacology (Berl) 191:391-431. CrossRef Medline

Berridge KC, Robinson TE (1998) What is the role of dopamine in reward: hedonic impact, reward learning, or incentive salience? Brain Res Brain Res Rev 28:309-369. CrossRef Medline

Berrios J, Stamatakis AM, Kantak PA, McElligott ZA, Judson MC, Aita M, Rougie M, Stuber GD, Philpot BD (2016) Loss of UBE3A from THexpressing neurons suppresses GABA co-release and enhances VTA-NAc optical self-stimulation. Nat Commun 7:10702. CrossRef Medline

Bickel WK, DeGrandpre RJ, Higgins ST, Hughes JR (1990) Behavioral economics of drug self-administration. I. functional equivalence of response requirement and drug dose. Life Sci 47:1501-1510. CrossRef Medline

Bossert JM, Marchant NJ, Calu DJ, Shaham Y (2013) The reinstatement model of drug relapse: recent neurobiological findings, emerging research topics, and translational research. Psychopharmacology (Berl) 229:453476. CrossRef Medline

Brodnik ZD, España RA (2015) Dopamine uptake dynamics are preserved under isoflurane anesthesia. Neurosci Lett 606:129-134. CrossRef Medline

Bromberg-Martin ES, Matsumoto M, Hikosaka O (2010) Dopamine in motivational control: rewarding, aversive, and alerting. Neuron 68:815-834. CrossRef Medline

Bucher ES, Wightman RM (2015) Electrochemical analysis of neurotransmitters. Annu Rev Anal Chem (Palo Alto Calif) 8:239-261. CrossRef Medline

Buchta WC, Mahler SV, Harlan B, Aston-Jones GS, Riegel AC (2017) Dopamine terminals from the ventral tegmental area gate intrinsic inhibition in the prefrontal cortex. Physiol Rep 5:e13198. CrossRef Medline

Chang SE, Todd TP, Smith KS (2018) Paradoxical accentuation of motivation following accumbens-pallidum disconnection. Neurobiol Learn Mem 149:39-45. CrossRef Medline

Chaudhury D, Walsh JJ, Friedman AK, Juarez B, Ku SM, Koo JW, Ferguson D, Tsai HC, Pomeranz L, Christoffel DJ, Nectow AR, Ekstrand M, Domingos A, Mazei-Robison MS, Mouzon E, Lobo MK, Neve RL, Friedman JM, Russo SJ, Deisseroth K, et al. (2013) Rapid regulation of depressionrelated behaviours by control of midbrain dopamine neurons. Nature 493:532-536. CrossRef Medline 
Clark JJ, Hollon NG, Phillips PE (2012) Pavlovian valuation systems in learning and decision making. Curr Opin Neurobiol 22:1054-1061. CrossRef Medline

Corbit LH, Muir JL, Balleine BW (2001) The role of the nucleus accumbens in instrumental conditioning: evidence of a functional dissociation between accumbens core and shell. J Neurosci 21:3251-3260. CrossRef Medline

Di Chiara G (2002) Nucleus accumbens shell and core dopamine: differential role in behavior and addiction. Behav Brain Res 137:75-114. CrossRef Medline

Dobi A, Margolis EB, Wang HL, Harvey BK, Morales M (2010) Glutamatergic and nonglutamatergic neurons of the ventral tegmental area establish local synaptic contacts with dopaminergic and nondopaminergic neurons. J Neurosci 30:218-229. CrossRef Medline

Edwards NJ, Tejeda HA, Pignatelli M, Zhang S, McDevitt RA, Wu J, Bass CE, Bettler B, Morales M, Bonci A (2017) Circuit specificity in the inhibitory architecture of the VTA regulates cocaine-induced behavior. Nat Neurosci 20:438-448. CrossRef Medline

Eldridge MA, Lerchner W, Saunders RC, Kaneko H, Krausz KW, Gonzalez FJ, Ji B, Higuchi M, Minamimoto T, Richmond BJ (2016) Chemogenetic disconnection of monkey orbitofrontal and rhinal cortex reversibly disrupts reward value. Nat Neurosci 19:37-39. CrossRef Medline

España RA, Oleson EB, Locke JL, Brookshire BR, Roberts DC, Jones SR (2010) The hypocretin-orexin system regulates cocaine self-administration via actions on the mesolimbic dopamine system. Eur J Neurosci 31:336-348. CrossRef Medline

Everitt BJ, Belin D, Economidou D, Pelloux Y, Dalley JW, Robbins TW (2008) Review. neural mechanisms underlying the vulnerability to develop compulsive drug-seeking habits and addiction. Philos Trans R Soc Lond B Biol Sci 363:3125-3135. CrossRef Medline

Faget L, Zell V, Souter E, McPherson A, Ressler R, Gutierrez-Reed N, Yoo JH, Dulcis D, Hnasko TS (2018) Opponent control of behavioral reinforcement by inhibitory and excitatory projections from the ventral pallidum. Nat Commun 9:849. CrossRef Medline

Farrell MR, Schoch H, Mahler SV (2018) Modeling cocaine relapse in rodents: behavioral considerations and circuit mechanisms. Prog Neuropsychopharmacol Biol Psychiatry 87:33-47. CrossRef Medline

Ferguson SM, Eskenazi D, Ishikawa M, Wanat MJ, Phillips PE, Dong Y, Roth BL, Neumaier JF (2011) Transient neuronal inhibition reveals opposing roles of indirect and direct pathways in sensitization. Nat Neurosci 14:2224. CrossRef Medline

Ferguson SM, Phillips PE, Roth BL, Wess J, Neumaier JF (2013) Directpathway striatal neurons regulate the retention of decision-making strategies. J Neurosci 33:11668-11676. CrossRef Medline

Ferris MJ, Calipari ES, Yorgason JT, Jones SR (2013) Examining the complex regulation and drug-induced plasticity of dopamine release and uptake using voltammetry in brain slices. ACS Chem Neurosci 4:693-703. CrossRef Medline

Fields HL, Margolis EB (2015) Understanding opioid reward. Trends Neurosci 38:217-225. CrossRef Medline

Fiorillo CD, Williams JT (2000) Cholinergic inhibition of ventral midbrain dopamine neurons. J Neurosci 20:7855-7860. CrossRef Medline

Floresco SB, Magyar O (2006) Mesocortical dopamine modulation of executive functions: beyond working memory. Psychopharmacology (Berl) 188:567-585. CrossRef Medline

Floresco SB, McLaughlin RJ, Haluk DM (2008) Opposing roles for the nucleus accumbens core and shell in cue-induced reinstatement of foodseeking behavior. Neuroscience 154:877-884. CrossRef Medline

Foster DJ, Gentry PR, Lizardi-Ortiz JE, Bridges TM, Wood MR, Niswender CM, Sulzer D, Lindsley CW, Xiang Z, Conn PJ (2014) M5 receptor activation produces opposing physiological outcomes in dopamine neurons depending on the receptor's location. J Neurosci 34:3253-3262. CrossRef Medline

Gantz SC, Bunzow JR, Williams JT (2013) Spontaneous inhibitory synaptic currents mediated by a G protein-coupled receptor. Neuron 78:807-812. CrossRef Medline

Ge F, Wang N, Cui C, Li Y, Liu Y, Ma Y, Liu S, Zhang H, Sun X (2017) Glutamatergic projections from the entorhinal cortex to dorsal dentate gyrus mediate context-induced reinstatement of heroin seeking. Neuropsychopharmacology 42:1860-1870. CrossRef Medline

Georges F, Aston-Jones G (2002) Activation of ventral tegmental area cells by the bed nucleus of the stria terminalis: a novel excitatory amino acid input to midbrain dopamine neurons. J Neurosci 22:5173-5187. CrossRef Medline

Gomez JL, Bonaventura J, Lesniak W, Mathews WB, Sysa-Shah P, Rodriguez LA, Ellis RJ, Richie CT, Harvey BK, Dannals RF, Pomper MG, Bonci A, Michaelides M (2017) Chemogenetics revealed: DREADD occupancy and activation via converted clozapine. Science 357:503-507. CrossRef Medline

Gourley SL, Taylor JR (2016) Going and stopping: dichotomies in behavioral control by the prefrontal cortex. Nat Neurosci 19:656-664. CrossRef Medline

Gourley SL, Zimmermann KS, Allen AG, Taylor JR (2016) The medial orbitofrontal cortex regulates sensitivity to outcome value. J Neurosci 36: 4600-4613. CrossRef Medline

Grace AA, Bunney BS (1984) The control of firing pattern in nigral dopamine neurons: burst firing. J Neurosci 4:2877-2890. CrossRef Medline

Grace AA, Floresco SB, Goto Y, Lodge DJ (2007) Regulation of firing of dopaminergic neurons and control of goal-directed behaviors. Trends Neurosci 30:220-227. CrossRef Medline

Grayson DS, Bliss-Moreau E, Machado CJ, Bennett J, Shen K, Grant KA, Fair DA, Amaral DG (2016) The rhesus monkey connectome predicts disrupted functional networks resulting from pharmacogenetic inactivation of the amygdala. Neuron 91:453-466. CrossRef Medline

Hamid AA, Pettibone JR, Mabrouk OS, Hetrick VL, Schmidt R, Vander Weele CM, Kennedy RT, Aragona BJ, Berke JD (2016) Mesolimbic dopamine signals the value of work. Nat Neurosci 19:117-126. CrossRef Medline

Hamlin AS, Clemens KJ, McNally GP (2008) Renewal of extinguished cocaine-seeking. Neuroscience 151:659-670. CrossRef Medline

Hearing MC, Zink AN, Wickman K (2012) Cocaine-induced adaptations in metabotropic inhibitory signaling in the mesocorticolimbic system. Rev Neurosci 23:325-351. CrossRef Medline

Heidenreich BA, Mailman RB, Nichols DE, Napier TC (1995) Partial and full dopamine D1 agonists produce comparable increases in ventral pallidal neuronal activity: contribution of endogenous dopamine. J Pharmacol Exp Ther 273:516-525. Medline

Hnasko TS, Hjelmstad GO, Fields HL, Edwards RH (2012) Ventral tegmental area glutamate neurons: electrophysiological properties and projections. J Neurosci 32:15076-15085. CrossRef Medline

Hursh SR (1993) Behavioral economics of drug self-administration: an introduction. Drug Alcohol Depend 33:165-172. CrossRef Medline

Hursh SR, Silberberg A (2008) Economic demand and essential value. Psychol Rev 115:186-198. CrossRef Medline

Johnson KA, Lovinger DM (2016) Presynaptic G protein-coupled receptors: gatekeepers of addiction? Front Cell Neurosci 10:264. CrossRef Medline

Kalivas PW, McFarland K (2003) Brain circuitry and the reinstatement of cocaine-seeking behavior. Psychopharmacology (Berl) 168:44-56. CrossRef Medline

Kaufling J, Aston-Jones G (2015) Persistent adaptations in afferents to ventral tegmental dopamine neurons after opiate withdrawal. J Neurosci 35:10290-10303. CrossRef Medline

Keiflin R, Janak PH (2015) Dopamine prediction errors in reward learning and addiction: from theory to neural circuitry. Neuron 88:247-263. CrossRef Medline

Lammel S, Tye KM, Warden MR (2014a) Progress in understanding mood disorders: optogenetic dissection of neural circuits. Genes Brain Behav 13:38-51. CrossRef Medline

Lammel S, Lim BK, Malenka RC (2014b) Reward and aversion in a heterogeneous midbrain dopamine system. Neuropharmacology 76:351-359. CrossRef Medline

Lapish CC, Seamans JK, Chandler LJ (2006) Glutamate-dopamine cotransmission and reward processing in addiction. Alcohol Clin Exp Res 30: 1451-1465. CrossRef Medline

Lichtenberg NT, Pennington ZT, Holley SM, Greenfield VY, Cepeda C, Levine MS, Wassum KM (2017) Basolateral amygdala to orbitofrontal cortex projections enable cue-triggered reward expectations. J Neurosci 37:8374-8384. CrossRef Medline

Lodge DJ, Grace AA (2006) The hippocampus modulates dopamine neuron responsivity by regulating the intensity of phasic neuron activation. Neuropsychopharmacology 31:1356-1361. CrossRef Medline

Loweth JA, Tseng KY, Wolf ME (2013) Using metabotropic glutamate re- 
ceptors to modulate cocaine's synaptic and behavioral effects: mGluR1 finds a niche. Curr Opin Neurobiol 23:500-506. CrossRef Medline

Luo AH, Georges FE, Aston-Jones GS (2008) Novel neurons in ventral tegmental area fire selectively during the active phase of the diurnal cycle. Eur J Neurosci 27:408-422. CrossRef Medline

Lüscher C, Malenka RC (2011) Drug-evoked synaptic plasticity in addiction: from molecular changes to circuit remodeling. Neuron 69:650-663. CrossRef Medline

MacLaren DA, Browne RW, Shaw JK, Krishnan Radhakrishnan S, Khare P, España RA, Clark SD (2016) Clozapine $N$-oxide administration produces behavioral effects in Long-Evans rats: implications for designing DREADD experiments. eNeuro 3:ENEURO.0219-16.2016. CrossRef Medline

Mahler SV, Aston-Jones G (2018) CNO evil? Considerations for the use of DREADDs in behavioral neuroscience. Neuropsychopharmacology 43: 934-936. CrossRef Medline

Mahler SV, Berridge KC (2009) Which cue to "want"? Central amygdala opioid activation enhances and focuses incentive salience on a prepotent reward cue. J Neurosci 29:6500-6513. CrossRef Medline

Mahler SV, Berridge KC (2012) What and when to "want"? amygdala-based focusing of incentive salience upon sugar and sex. Psychopharmacology (Berl) 221:407-426. CrossRef Medline

Mahler SV, Smith RJ, Aston-Jones G (2013) Interactions between VTA orexin and glutamate in cue-induced reinstatement of cocaine seeking in rats. Psychopharmacology (Berl) 226:687-698. CrossRef Medline

Mahler SV, Vazey EM, Beckley JT, Keistler CR, McGlinchey EM, Kaufling J, Wilson SP, Deisseroth K, Woodward JJ, Aston-Jones G (2014) Designer receptors show role for ventral pallidum input to ventral tegmental area in cocaine seeking. Nat Neurosci 17:577-585. CrossRef Medline

Manvich DF, Webster KA, Foster SL, Farrell MS, Ritchie JC, Porter JH, Weinshenker D (2018) The DREADD agonist clozapine N-oxide (CNO) is reverse-metabolized to clozapine and produces clozapine-like interoceptive stimulus effects in rats and mice. Sci Rep 8:3840. CrossRef Medline

Martin-Fardon R, Weiss F (2013) Modeling relapse in animals. Curr Top Behav Neurosci 13:403-432. CrossRef Medline

McGlinchey EM, Aston-Jones G (2018) Dorsal hippocampus drives context-induced cocaine seeking via inputs to lateral septum. Neuropsychopharmacology 43:987-1000. CrossRef Medline

Meye FJ, van Zessen R, Smidt MP, Adan RA, Ramakers GM (2012) Morphine withdrawal enhances constitutive mu-opioid receptor activity in the ventral tegmental area. J Neurosci 32:16120-16128. CrossRef Medline

Meye FJ, Ramakers GM, Adan RA (2014) The vital role of constitutive GPCR activity in the mesolimbic dopamine system. Transl Psychiatry 4:e361. CrossRef Medline

Moorman DE, James MH, McGlinchey EM, Aston-Jones G (2015) Differential roles of medial prefrontal subregions in the regulation of drug seeking. Brain Res 1628:130-146. CrossRef Medline

Nagai Y, Kikuchi E, Lerchner W, Inoue KI, Ji B, Eldridge MA, Kaneko H, Kimura Y, Oh-Nishi A, Hori Y, Kato Y, Hirabayashi T, Fujimoto A, Kumata K, Zhang MR, Aoki I, Suhara T, Higuchi M, Takada M, Richmond $\mathrm{BJ}$, et al. (2016) PET imaging-guided chemogenetic silencing reveals a critical role of primate rostromedial caudate in reward evaluation. Nat Commun 7:13605. CrossRef Medline

Nakajima K, Cui Z, Li C, Meister J, Cui Y, Fu O, Smith AS, Jain S, Lowell BB, Krashes MJ, Wess J (2016) Gs-coupled GPCR signalling in AgRP neurons triggers sustained increase in food intake. Nat Commun 7:10268. CrossRef Medline

Oleson EB, Richardson JM, Roberts DC (2011) A novel IV cocaine selfadministration procedure in rats: differential effects of dopamine, serotonin, and GABA drug pre-treatments on cocaine consumption and maximal price paid. Psychopharmacology (Berl) 214:567-577. CrossRef Medline

Ostlund SB, Wassum KM, Murphy NP, Balleine BW, Maidment NT (2011) Extracellular dopamine levels in striatal subregions track shifts in motivation and response cost during instrumental conditioning. J Neurosci 31:200-207. CrossRef Medline

Peters J, LaLumiere RT, Kalivas PW (2008) Infralimbic prefrontal cortex is responsible for inhibiting cocaine seeking in extinguished rats. J Neurosci 28:6046-6053. CrossRef Medline

Pignatelli M, Bonci A (2015) Role of dopamine neurons in reward and aversion: a synaptic plasticity perspective. Neuron 86:1145-1157. CrossRef Medline
Riegel AC, Williams JT (2008) CRF facilitates calcium release from intracellular stores in midbrain dopamine neurons. Neuron 57:559-570. CrossRef Medline

Roeper J (2013) Dissecting the diversity of midbrain dopamine neurons. Trends Neurosci 36:336-342. CrossRef Medline

Root DH, Mejias-Aponte CA, Zhang S, Wang HL, Hoffman AF, Lupica CR, Morales M (2014) Single rodent mesohabenular axons release glutamate and GABA. Nat Neurosci 17:1543-1551. CrossRef Medline

Saddoris MP, Sugam JA, Cacciapaglia F, Carelli RM (2013) Rapid dopamine dynamics in the accumbens core and shell: learning and action. Front Biosci (Elite Ed) 5:273-288. CrossRef Medline

Salamone JD, Correa M (2012) The mysterious motivational functions of mesolimbic dopamine. Neuron 76:470-485. CrossRef Medline

Saunders BT, Richard JM, Margolis EB, Janak PH (2018) Dopamine neurons create pavlovian conditioned stimuli with circuit-defined motivational properties. Nat Neurosci 21:1072-1083. CrossRef Medline

Schultz W (2016) Dopamine reward prediction-error signalling: a twocomponent response. Nat Rev Neurosci 17:183-195. CrossRef Medline

Shen Y, Fu WY, Cheng EY, Fu AK, Ip NY (2013) Melanocortin-4 receptor regulates hippocampal synaptic plasticity through a protein kinase A-dependent mechanism. J Neurosci 33:464-472. CrossRef Medline

Smith KS, Berridge KC (2007) Opioid limbic circuit for reward: interaction between hedonic hotspots of nucleus accumbens and ventral pallidum. J Neurosci 27:1594-1605. CrossRef Medline

Stachniak TJ, Ghosh A, Sternson SM (2014) Chemogenetic synaptic silencing of neural circuits localizes a hypothalamus- $>$ midbrain pathway for feeding behavior. Neuron 82:797-808. CrossRef Medline

Stamatakis AM, Jennings JH, Ung RL, Blair GA, Weinberg RJ, Neve RL, Boyce F, Mattis J, Ramakrishnan C, Deisseroth K, Stuber GD (2013) A unique population of ventral tegmental area neurons inhibits the lateral habenula to promote reward. Neuron 80:1039-1053. CrossRef Medline

Steinberg EE, Keiflin R, Boivin JR, Witten IB, Deisseroth K, Janak PH (2013) A causal link between prediction errors, dopamine neurons and learning. Nat Neurosci 16:966-973. CrossRef Medline

Stewart J (2000) Pathways to relapse: the neurobiology of drug- and stressinduced relapse to drug-taking. J Psychiatry Neurosci 25:125-136. Medline

Stout KA, Dunn AR, Lohr KM, Alter SP, Cliburn RA, Guillot TS, Miller GW (2016) Selective enhancement of dopamine release in the ventral pallidum of methamphetamine-sensitized mice. ACS Chem Neurosci 7:1364-1373. CrossRef Medline

Sulzer D, Joyce MP, Lin L, Geldwert D, Haber SN, Hattori T, Rayport S (1998) Dopamine neurons make glutamatergic synapses in vitro. J Neurosci 18:4588-4602. CrossRef Medline

Suto N, Wise RA (2011) Satiating effects of cocaine are controlled by dopamine actions in the nucleus accumbens core. J Neurosci 31:17917-17922. CrossRef Medline

Tooley J, Marconi L, Alipio JB, Matikainen-Ankney B, Georgiou P, Kravitz AV, Creed MC (2018) Glutamatergic ventral pallidal neurons modulate activity of the habenula-tegmental circuitry and constrain reward seeking. Biol Psychiatry 83:1012-1023. CrossRef Medline

Tritsch NX, Ding JB, Sabatini BL (2012) Dopaminergic neurons inhibit striatal output through non-canonical release of GABA. Nature 490:262-266. CrossRef Medline

Tritsch NX, Granger AJ, Sabatini BL (2016) Mechanisms and functions of GABA co-release. Nat Rev Neurosci 17:139-145. CrossRef Medline

Trudeau LE, Hnasko TS, Wallén-Mackenzie A, Morales M, Rayport S, Sulzer D (2014) The multilingual nature of dopamine neurons. Prog Brain Res 211:141-164. CrossRef Medline

Tsai HC, Zhang F, Adamantidis A, Stuber GD, Bonci A, de Lecea L, Deisseroth K (2009) Phasic firing in dopaminergic neurons is sufficient for behavioral conditioning. Science 324:1080-1084. CrossRef Medline

Tye KM, Mirzabekov JJ, Warden MR, Ferenczi EA, Tsai HC, Finkelstein J, Kim SY, Adhikari A, Thompson KR, Andalman AS, Gunaydin LA, Witten IB, Deisseroth K (2013) Dopamine neurons modulate neural encoding and expression of depression-related behaviour. Nature 493:537-541. CrossRef Medline

Ungless MA, Grace AA (2012) Are you or aren't you? Challenges associated with physiologically identifying dopamine neurons. Trends Neurosci 35: 422-430. CrossRef Medline

Upright NA, Brookshire SW, Schnebelen W, Damatac CG, Hof PR, Browning PGF, Croxson PL, Rudebeck PH, Baxter MG (2018) Behavioral effect of 
chemogenetic inhibition is directly related to receptor transduction levels in rhesus monkeys. J Neurosci 38:7969-7975. CrossRef Medline

Wang XF, Liu JJ, Xia J, Liu J, Mirabella V, Pang ZP (2015) Endogenous glucagon-like peptide-1 suppresses high-fat food intake by reducing synaptic drive onto mesolimbic dopamine neurons. Cell Rep 12:726-733. CrossRef Medline

Wenzel JM, Cheer JF (2018) Endocannabinoid regulation of reward and reinforcement through interaction with dopamine and endogenous opioid signaling. Neuropsychopharmacology 43:103-115. CrossRef Medline

Williams CL, Buchta WC, Riegel AC (2014) CRF-R2 and the heterosynaptic regulation of VTA glutamate during reinstatement of cocaine seeking. J Neurosci 34:10402-10414. CrossRef Medline

Willuhn I, Burgeno LM, Everitt BJ, Phillips PE (2012) Hierarchical recruitment of phasic dopamine signaling in the striatum during the progression of cocaine use. Proc Natl Acad Sci U S A 109:20703-20708. CrossRef Medline

Witten IB, Steinberg EE, Lee SY, Davidson TJ, Zalocusky KA, Brodsky M, Yizhar O, Cho SL, Gong S, Ramakrishnan C, Stuber GD, Tye KM, Janak PH, Deisseroth K (2011) Recombinase-driver rat lines: tools, techniques, and optogenetic application to dopamine-mediated reinforcement. Neuron 72:721-733. CrossRef Medline

Yorgason JT, España RA, Jones SR (2011) Demon voltammetry and analysis software: analysis of cocaine-induced alterations in dopamine signaling using multiple kinetic measures. J Neurosci Methods 202:158-164. CrossRef Medline

Zhang S, Qi J, Li X, Wang HL, Britt JP, Hoffman AF, Bonci A, Lupica CR, Morales M (2015) Dopaminergic and glutamatergic microdomains in a subset of rodent mesoaccumbens axons. Nat Neurosci 18:386-392. CrossRef Medline 